\title{
A new Route toward (Aminomethyl)cyclopentadienide Ligands and their Group 4 Metal Complexes.
}

\author{
Quentin Bonnin,,${ }^{[\mathrm{a}]}$ Sook-Yen Wong, ${ }^{[\mathrm{a}]}$ Cédric Balan, ${ }^{[\mathrm{a}]}$ Virginie Comte, ${ }^{[\mathrm{a}]}$ Raluca Malacea, ${ }^{[\mathrm{a}]}$ Marie-José \\ Penouilh, ${ }^{[a]}$ Philippe Richard, ${ }^{[a]}$ Gerald Kehr, ${ }^{[b]}$ Adrien T. Normand, ${ }^{[a]}$ Gerhard Erker ${ }^{*[b]}$ and Pierre Le \\ Gendre*[a]
}

\begin{abstract}
A new synthetic method is described, by which $\mathrm{N}$ functionalized cyclopentadienide ligands are synthesized, via the nucleophilic substitution of sodium cyclopentadienide onto Katritzky's (benzotriazolyl) compounds. This route enables the introduction of bulky and basic amines separated from the cyclopentadienyl ring by a methylene spacer, and thus represents a valuable alternative to the general fulvene route. The resulting ligands have been coordinated to titanium and zirconium, producing a series of discrete metallocene derivatives with a pendant amine arm. These complexes are extremely sensitive towards moisture, but they can easily be converted into benchtop-stable ammonium chloride derivatives. The ligands and their complexes have been fully characterized by NMR and IR spectroscopy, elemental analysis and/or high resolution ESIMS. The solid state structures of ten complexes have been established by single crystal X-ray diffraction analysis.
\end{abstract}

\section{Introduction}

Over the last decades, amino- and amido-functionalized cyclopentadienyl early metal complexes have attracted increased interest for their use in polymerization catalysis, ${ }^{[1,2]}$ organic catalysis, ${ }^{[3]}$ and also for therapeutic purposes. ${ }^{[4]}$ The incorporation of amino or amido functions on the cyclopentadienyl ring allows to tailor the properties of these complexes and, consequently, to achieve optimal performance. One drawback of this approach is that the synthesis of these complexes is not straightforward. Unlike ferrocene, ${ }^{[5]}$ lithiation and subsequently functionalization of early metallocenes is usually not feasible. ${ }^{[6]}$ Instead, the synthesis of a functionalized cyclopentadienyl ligand is required before metalation. Several synthetic routes already exist towards aminofunctionalized cyclopentadienyl ligands. ${ }^{[7]}$ In the case of (aminomethyl)cyclopentadienyl ligand, fulvenes and aminofulvenes appear as ubiquitous intermediates. ${ }^{[8]}$ The carbolithiation

[a] Dr. Q. Bonnin, S.-Y. Wong, C. Balan, Dr. V. Comte, Dr. Raluca Malacea, M.-J. Penouilh, Dr. P. Richard, Dr. A. T. Normand, Prof. P. Le Gendre

Institut de Chimie Moléculaire de l'Université de Bourgogne (ICMUB, UMR-CNRS 6302)

Université de Bourgogne Franche-Comté

9, av. Alain Savary, F-21078 DIJON Cedex, France

E-mail: pierre.le-gendre@u-bourgogne.fr

[b] Dr. G. Kehr, Prof. G. Erker

Organisch-Chemisches Institut

Westfälische Wilhelms-Universität Münster

Corrensstraße 40, 48149 Münster, Germany

E-mail: erker@uni-muenster.de

Supporting information for this article is given via a link at the end of the document. of the 6-(dimethylamino)fulvene using alkyl, aryl or heteroaryl lithium species leads to a variety of dimethylamino-functionalized cyclopentadienides (Scheme 1, eq. 1). ${ }^{[4,9]}$ In addition, it has been shown that 6-(amino)fulvene can undergo exchange reaction with morpholine or (methoxymethyl)pyrrolidine to furnish the corresponding fulvenes derivatives which can be further reduced to amino-functionalized cyclopentadienide ligands (eq. 2). ${ }^{[10]}$

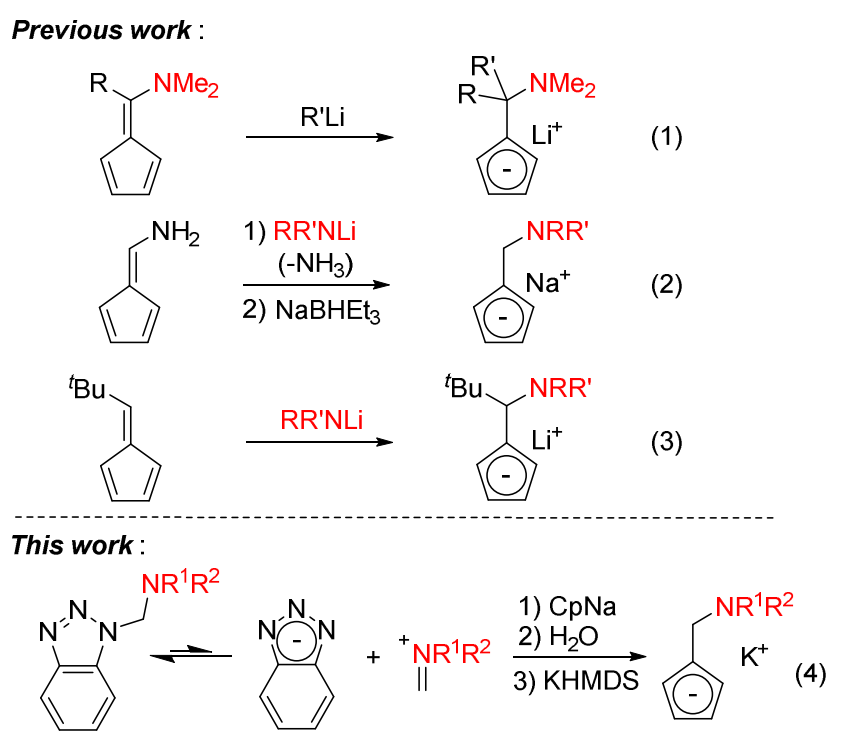

Scheme 1. Synthetic routes towards (aminomethyl)cyclopentadienyl ligand.

The introduction of an amino function to the cyclopentadienyl moiety can also be realized by adding Li-amido reagents at the C6 carbon atom of an aliphatic fulvene but this reaction is limited to non "enolizable" fulvenes such as 6-t-butylpentafulvene (eq. 3) or tetramethylpentafulvene because of the basic character of the Li-amido reagents. ${ }^{[2,11]}$ Aware of these limitations and with the aim of introducing bulky and basic tertiary amines close to the metal center, we envisioned another synthetic strategy based on the addition of the cyclopentadienide anion to aminomethylbenzotriazole derivatives (eq.4). In solution, these compounds - developed mainly by Katritzky - exist in equilibrium with highly electrophilic iminium salts and, therefore, represent valuable candidates for our purpose. ${ }^{[12]}$ Herein we describe the synthesis of (aminomethyl)cyclopentadienide ligands using this new benzotriazole route. Preliminary metalation studies with early metal precursors $(\mathrm{Ti}, \mathrm{Zr})$ are reported.

\section{Results and Discussion}


We thus first synthesized several benzotriazole adducts according to the procedures described in the literature. ${ }^{[13]}$ The reaction of formaldehyde with $\mathrm{N}$-methylbenzylamine, pyrrolidine, diisopropylamine, dibenzylamine or tetramethylpiperidine and one equivalent of benzotriazole produced 1(aminomethyl)benzotriazole substrates. We next reacted these compounds with sodium cyclopentadienide in ether (Scheme 2), and monitored the reaction by TLC and/or GCMS. Once the 1(aminomethyl)benzotriazole was fully consumed, the reaction mixture was successively filtered, hydrolyzed, dried over magnesium sulfate and evaporated to dryness. Addition of a toluene solution of KHMDS to the mixture of cyclopentadiene isomers re-solubilized in diethyl ether led to the target potassium amino-functionalised cyclopentadienides (1-5) in 39-86\% yields. The anions were characterized by ${ }^{1} \mathrm{H},{ }^{13} \mathrm{C}$ NMR spectroscopy and high resolution ESI-MS. The ${ }^{1} \mathrm{H}$ NMR spectra of compounds 1-5 show a similar pattern, two multiplets (AA'BB' spin system) in the range of 5.2-5.4 ppm and one singlet between 3.3-3.5 ppm for the bridging $\mathrm{CH}_{2}$ protons.

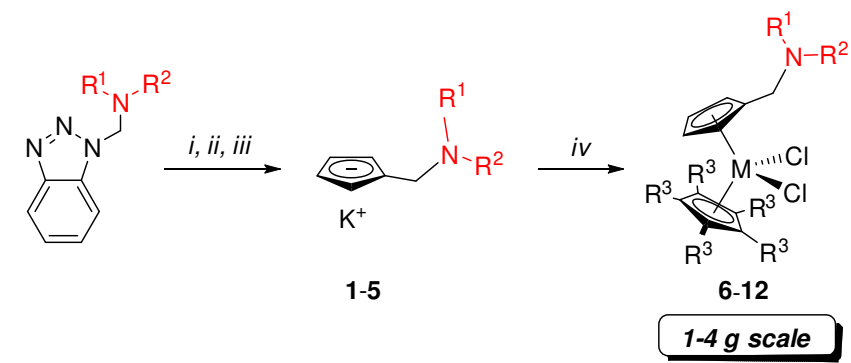

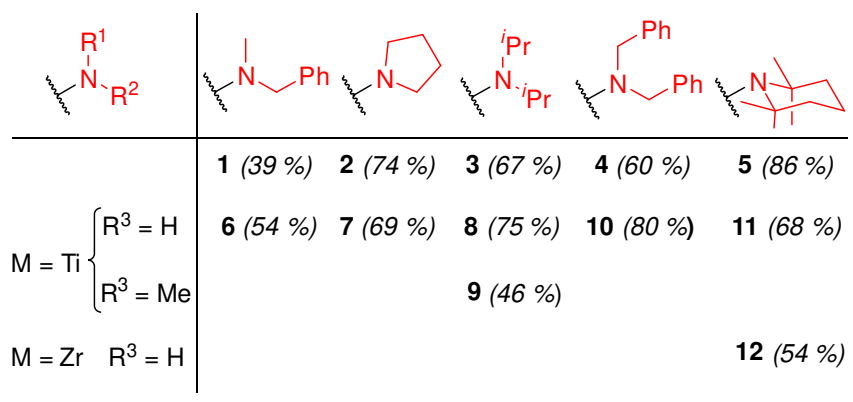

Scheme 2. Reagents and conditions: i) $\mathrm{CpNa}_{2} \mathrm{Et}_{2} \mathrm{O}$, r.t., $4 \mathrm{~h}$ (for benzyl derivatives, reflux, $12 \mathrm{~h}$ ); ii) $\mathrm{H}_{2} \mathrm{O}$; iii) $\mathrm{KHMDS}$, toluene / $\mathrm{Et}_{2} \mathrm{O}, 0^{\circ} \mathrm{C}\left(10^{\prime}\right)$ to r.t. (2 h); iv) $\mathrm{C}_{5} \mathrm{H}_{5} \mathrm{MCl}_{3}(\mathrm{M}=\mathrm{Ti}, \mathrm{Zr})$, or $\mathrm{C}_{5} \mathrm{Me}_{5} \mathrm{TiCl}_{3}$, toluene / $\mathrm{THF},-30^{\circ} \mathrm{C}\left(30^{\prime}\right)$ to r.t., $12 \mathrm{~h}$.

With these anions in hands, we next focused on the synthesis of early metallocene complexes with one pendant amine function and proceeded as follow: the amino-functionalised cyclopentadienyl anion in THF solution was added dropwise at $-30{ }^{\circ} \mathrm{C}$ to a toluene solution containing one equivalent of $\mathrm{CpTiCl}_{3}$ or $\mathrm{Cp}^{\star} \mathrm{TiCl}_{3}$. The reaction was allowed to warm to room temperature and stirred at this temperature for $12 \mathrm{~h}$. The resulting dark red solution was evaporated, then the residue was solubilized in $\mathrm{CH}_{2} \mathrm{Cl}_{2}$ and the solution was filtered. The target complexes 6-11 were then obtained by precipitation with pentane as highly moisture sensitive red powders in $46-80 \%$ yields. Using a similar procedure, the tetramethylpiperidine-functionalized zirconocene complex 12 was obtained in 54\% yield from the potassium cyclopentadienide salt 5 and $\mathrm{CpZrCl}_{3}$. Complexes 612 were characterized by ${ }^{1} \mathrm{H},{ }^{13} \mathrm{C},{ }^{15} \mathrm{~N}$ NMR spectroscopy, IR spectroscopy, elemental analysis and high resolution ESI-MS (see Supporting Information). The ${ }^{1} \mathrm{H}$ NMR spectra of complexes 6-12 show downfield shifted signals for the $\mathrm{Cp}$ ' ring and bridging $\mathrm{CH}_{2}$ protons $(\Delta \bar{\delta}=0.1-1.4 \mathrm{ppm})$ compared to the anionic ligands. The ${ }^{15} \mathrm{~N}$ NMR spectra of complexes 6-12 display single resonance between $\delta=-339$ and $\delta=-309 \mathrm{ppm}$, a range comparable to that observed for other amino-functionalised group 4 organometallic complexes. ${ }^{[14]}$

Single crystals of complexes $\mathbf{9 - 1 2}$ suitable for X-ray diffraction analysis were obtained by slow diffusion of pentane into saturated $\mathrm{CH}_{2} \mathrm{Cl}_{2}$ solutions of the complexes. ORTEP views of these complexes are presented in Figure 1.
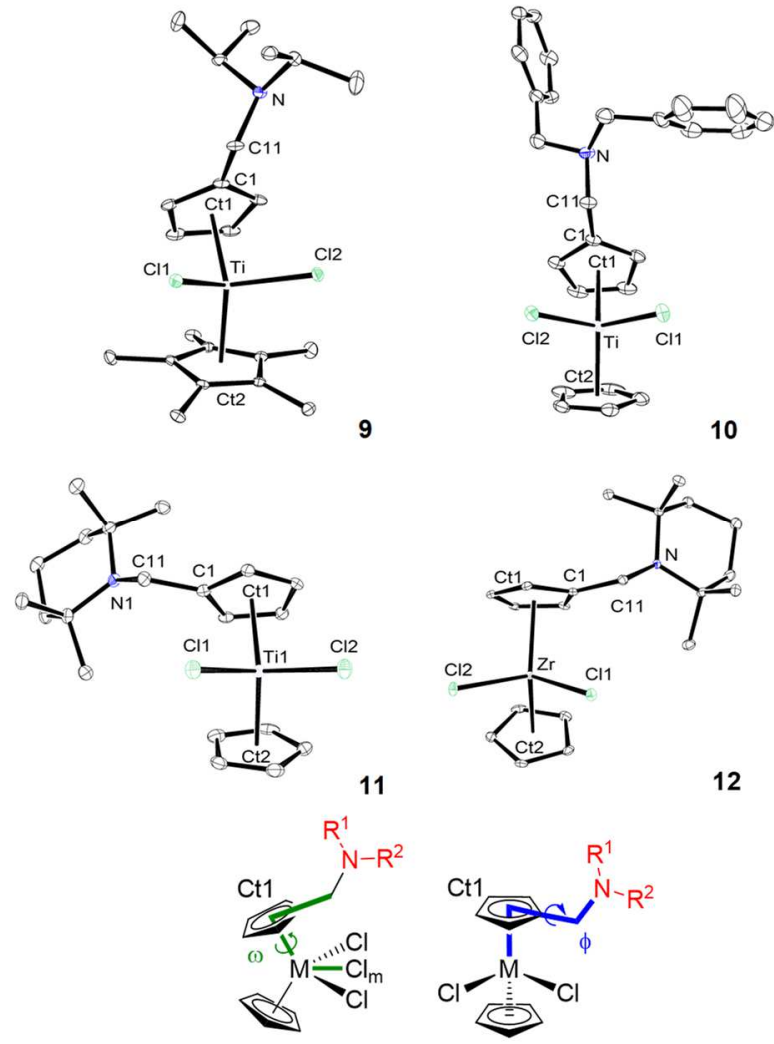

Figure 1. ORTEP views of complexes 9-12 (hydrogen atoms as well as the second independent molecules for $\mathbf{9}$ and $\mathbf{1 1}$ are omitted for clarity) and definitions of the torsion angles $\omega$ and $\phi\left(\mathrm{Cl}_{\mathrm{m}}\right.$ is the centroid of $\left.\mathrm{Cl} 1 / \mathrm{Cl} 2\right) . \mathrm{Ct} 1$ and $\mathrm{Ct} 2$ are centroids of $\mathrm{Cp}$ ' and $\mathrm{Cp}\left(\mathrm{Cp}^{\star}\right)$ rings, respectively.

Table 1. Relevant bond distances $(\AA)$ and angles $\left(^{\circ}\right)$ in compounds 9-12.

\begin{tabular}{lllll}
\hline & $9^{[\mathrm{a}]}$ & 10 & $11^{[\mathrm{a}]}$ & 12 \\
\hline M-Ct1 & $2.0690(11)$ & $2.0606(11)$ & $2.074(2)$ & $2.2123(12)$
\end{tabular}




\begin{tabular}{lllll} 
M-Ct2 & $2.0936(10)$ & $2.0598(12)$ & $2.061(2)$ & $2.2100(13)$ \\
M-Cl1 & $2.3602(7)$ & $2.3615(6)$ & $2.3613(14)$ & $2.4498(7)$ \\
M-Cl2 & $2.3705(7)$ & $2.3768(6)$ & $2.3790(13)$ & $2.4549(7)$ \\
Ct1-M-Ct2 & $131.78(4)$ & $131.12(5)$ & $131.39(9)$ & $130.76(5)$ \\
Cl1-M-Cl2 & $94.14(12)$ & $93.89(2)$ & $94.05(5)$ & $96.15(2)$ \\
$\omega$ & $-1.51(6)$ & $-5.35(7)$ & $-81.35(18)$ & $68.61(8)$ \\
$\phi$ & $147.67(13)$ & $179.88(15)$ & $-115.4(3)$ & $118.72(16)$ \\
\hline
\end{tabular}

[a] Structural parameters of one of the two independent molecules present in the cell are given.

The geometries of the three titanium complexes 9-11 are typically pseudo-tetrahedral with similar structural parameters (Table 1). The zirconium complex 12 shows similar geometry to complexes 9-11 with slightly longer $\mathrm{M}-\mathrm{Cl}$ bonds lengths and $\mathrm{M}-\mathrm{Ct}$ distances, consistent with the longer covalent radius of $\mathrm{Zr}$ vs $\mathrm{Ti}(\mathrm{Ti}=1.60(8)$

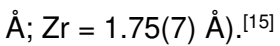

Despite these metric similarities, complexes 9-12 show startling orientational differences which are dependent on the steric properties of the amine moiety. These differences can be described by the torsion angles $\omega$ and $\phi$, which indicate the position of the amine moiety with respect to the $\mathrm{Cl}$ ligands $(\omega)$ and the Cp' ring $(\phi)$ (see Figure 1 for definitions).

Thus, in 9 and $\mathbf{1 0}$, the $\mathrm{CH}_{2}$ bridge is located to the open side of the bent metallocene, and lies above the $\mathrm{TiCl}_{2}$ fragment (torsion angle $\omega=-1.51(6)^{\circ}$ and $-5.35(7)^{\circ}$, respectively). In contrast, for compounds 11 and 12, the bulky TMP substituent is rotated from the bisecting position, leading to $\omega$ values of $-81.35(18)^{\circ}$ in 11 and $68.61(8)^{\circ}$ in 12 . The position of the $\mathrm{N}$ atom with respect to the $\mathrm{Cp}$ ' plane is also particularly noteworthy in complexes $\mathbf{1 1}$ and $\mathbf{1 2}$ compared to complexes 9 and 10 . Indeed whereas the $\mathrm{C}_{1} \mathrm{C}_{\mathrm{CH}} \mathrm{N}$ plane is more or less orthogonal to the Cp' ring in $\mathbf{9}$ and $\mathbf{1 0}(\phi=$ $147.67(3)^{\circ}$ and $179.88(15)^{\circ}$, respectively), this plane is tilted toward the $\mathrm{Cp}$ ' ring due to the steric hindrance of the bulky tetramethylpiperidine $\left(\phi=-115.4(3)^{\circ}\right.$ and $118.72(16)^{\circ}$, respectively).

It has been previously shown that the instability of amino titanocene toward moisture can be attenuated by protonating the amine function. ${ }^{[7]]}$ We conducted the protonation of complexes 6 8, 10 and 11 in hydrochloric acid-saturated solution of toluene and obtained the corresponding ammonium salts $13-17$ in $52-73 \%$ yields (Scheme 3). These turned out to be air and moisture-stable, and even water soluble. The protonation of the amine function has a profound impact on the shape of the ${ }^{1} \mathrm{H}$ NMR spectra of these complexes, by changing stereotopic relationships between atoms and/or groups. Thus the ${ }^{1} \mathrm{H}$ NMR spectrum of the chiral ammonium salt 13 shows four quartets centered at $\delta=7.07 / 6.97$, $6.60 / 6.57$ ppm for the pairs of diastereotopic Cp' protons, and four doublets of doublets centered at $\delta=4.38 / 4.04$ and $4.37 / 4.13 \mathrm{ppm}$ for the pairs of diastereotopic methylene protons. For the other ammonium salts, diastereotopic effects are also observed for the methylene protons of the pyrrolidine ring in $\mathbf{1 4}$, for the methyl protons of the isopropyl groups in 15, for the methylene protons of the benzyl groups in $\mathbf{1 6}$ and for both methyl and methylene protons of the tetramethylpyperidine in $\mathbf{1 7 .}$

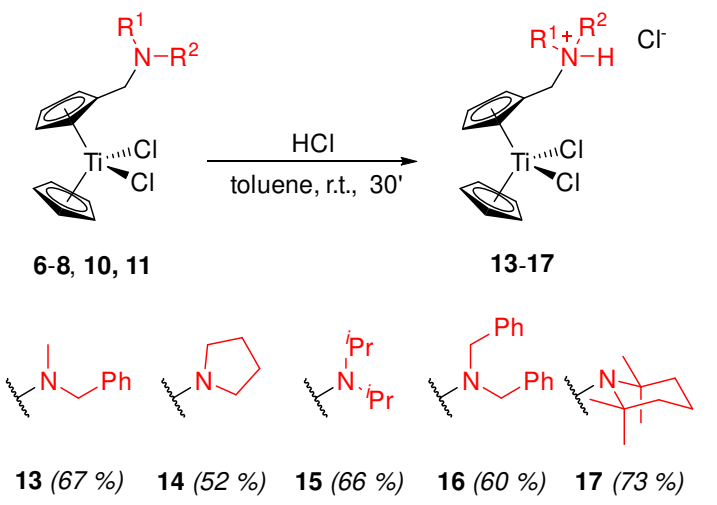

Scheme 3. Synthesis of the ammonium-functionalised titanocene complexes.

$X$-ray diffraction studies have been performed on single crystals of 14,15 and 17, and allowed to confirm their structures (Figure 2).

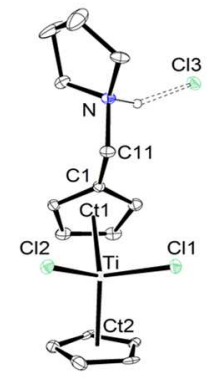

14

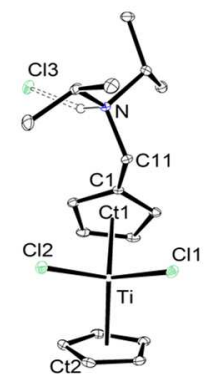

15

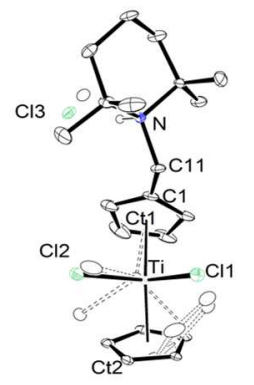

17
Figure 2. ORTEP view of 14, 15 and $\mathbf{1 7}$ (hydrogen atoms removed for clarity except $\mathrm{NH}$ as well as counter anion and solvent). Selected bond lengths $(\AA)$ and angles $\left({ }^{\circ}\right): 14: \mathrm{Ct} 1-\mathrm{Ti}=2.062(3), \mathrm{Ct} 2-\mathrm{Ti}=2.057(6), \mathrm{Cl} 1-\mathrm{Ti}=2.3477(16), \mathrm{Cl} 2-\mathrm{Ti}$ $=2.3645(16), \mathrm{Cl} 1-\mathrm{Ti}-\mathrm{Cl} 2=92.43(6), \mathrm{Ct} 1-\mathrm{Ti}-\mathrm{Ct} 2=131.9(2), \omega=-0.99(18), \phi=$ 176.1(4). 15: Ct1-Ti = 2.0617(6), Ct2-Ti = 2.0548(6), Cl1-Ti = 2.3461(4), Cl2-Ti $=2.3638(4), \mathrm{Cl} 1-\mathrm{Ti}-\mathrm{Cl} 2=92.920(13), \mathrm{Ct} 1-\mathrm{Ti}-\mathrm{Ct} 2=130.97(3), \omega=8.55(3), \phi=-$ 148.28(7). 17a (bisecting conformation): Ct1-Ti $=2.191(3), \mathrm{Ct} 2-\mathrm{Ti}=2.051(4)$, $\mathrm{Cl} 1-\mathrm{Ti}=2.335(3), \mathrm{Cl} 2-\mathrm{Ti}=2.363(5), \mathrm{Cl} 1-\mathrm{Ti}-\mathrm{Cl} 2=93.17(15), \mathrm{Ct} 1-\mathrm{Ti}-\mathrm{Ct} 2=$ 129.45(15), $\omega=16.43(15), \phi=-154.41(14) .17 b$ (non-bisecting conformation): $\mathrm{Ct} 1-\mathrm{Ti}=1.955(3), \mathrm{Ct} 2-\mathrm{Ti}=2.056(3), \mathrm{Cl} 1-\mathrm{Ti}=2.366(5), \mathrm{Cl} 2-\mathrm{Ti}=2.362(3), \mathrm{Cl} 1-$ $\mathrm{Ti}-\mathrm{Cl} 2=95.54(13), \mathrm{Ct} 1-\mathrm{Ti}-\mathrm{Ct} 2=127.00(14), \omega=86.6(2), \phi=-147.51(14)$.

The ammonium moieties, in complexes 14 and 15 adopt a bisecting position, above the $\mathrm{Cl}$ ligands like in the neutral complexes 9 and $10\left(\omega=-0.99(18)^{\circ}, 8.55(3)^{\circ}\right.$, respectively), and they also sit above the Cp' ring $\left(\phi=176.1(4)^{\circ},-148.28(7)^{\circ}\right.$, respectively). The crystal structure of $\mathbf{1 7}$ exhibits a disorder over two positions, this lead to two different conformations where the TMP moiety is either located in a bisecting position $(\omega=$ $16.43(15))$ or to the side $(\omega=86.6(2))$. These results suggest that 
the peculiar orientation of the TMP moiety in the solid-state structures of $\mathbf{1 1}$ and $\mathbf{1 2}$ is the result of subtle crystal packing effects and is not fixed in solution. Further support for this hypothesis comes from the ${ }^{1} \mathrm{H}$ NMR spectra of these complexes, which do not show any evidence for restricted rotation in solution. We also attempted the synthesis of 1,1'-bis(aminomethyl) group 4 metallocenes. The addition of the potassium cyclopentadienide 4 to $\mathrm{TiCl}_{4}(\mathrm{THF})_{2}$ in 2:1 ratio in $\mathrm{Et}_{2} \mathrm{O}$ gave the target complex 18, albeit in $15 \%$ yield (Scheme 4 ). In the zirconium complexes, the reaction of two equivalents of $\mathbf{4}$ with $\mathrm{ZrCl}_{4}$ gave the target bisaminozirconocene complex 19 in 31\% yield (Scheme 4). A similar reaction with the cyclopentadienide salt $\mathbf{3}$ afforded complex $\mathbf{2 0}$ in $76 \%$ yield.

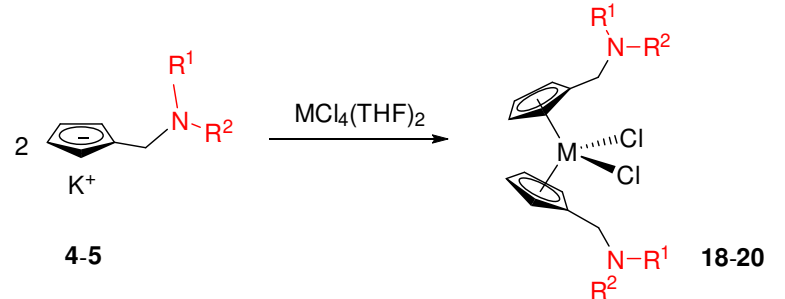

\begin{tabular}{l|ll} 
& \\
$M=\mathrm{Ti}$ & $\mathbf{1 8}(15 \%)$ & \\
$\mathrm{M}=\mathrm{Zr}$ & $\mathbf{1 9}(31 \%)$ & $\mathbf{2 0}(76 \%)$
\end{tabular}

Scheme 4. Reagents and conditions: $\mathrm{Et}_{2} \mathrm{O}(\mathrm{M}=\mathrm{Ti})$ or $\mathrm{THF}(\mathrm{M}=\mathrm{Zr}),-30^{\circ} \mathrm{C}\left(30^{\prime}\right)$ to r.t. $(12 \mathrm{~h})$.

The ${ }^{1} \mathrm{H}$ NMR spectrum of $\mathbf{1 8}$ shows the expected pattern for the $\mathrm{Ph}$ group at $\delta=7.36$ (ortho), 7.32 (meta) and 7.24 (para) ppm, two triplet-like signals for the Cp' protons at $\delta=6.35$ and $6.25 \mathrm{ppm}$ (AA'BB' spin system), and two broad signals at $\delta=3.53(8 \mathrm{H})$ and $3.52(4 \mathrm{H}) \mathrm{ppm}$ corresponding to the both methylene protons. The ${ }^{1} \mathrm{H}^{15} \mathrm{~N} \mathrm{HMBC}$ spectrum of $\mathbf{1 8}$ reveals that the $\mathrm{N}$ atom resonates at almost the same chemical shift as that of $\mathbf{1 0}(\delta=-327 \mathrm{ppm}$ for 18 vs $\delta=-328$ ppm for 10). Unsurprisingly, the ${ }^{1} \mathrm{H}$ NMR spectrum of zirconium complex 19 shows a set of signals comparable to those of its $\mathrm{Ti}$ analogue 18 , and the ${ }^{15} \mathrm{~N}$ chemical shift determined by ${ }^{1} \mathrm{H}^{15} \mathrm{~N} \mathrm{HMBC}$ is almost identical $(\delta=-328 \mathrm{ppm})$. In the case of zirconium complex 20, the signals of the protons from the $\mathrm{Cp}$ ' ring appear as two multiplets at $\delta=6.35$ and $6.33 \mathrm{ppm}$ in the ${ }^{1} \mathrm{H}$ NMR spectrum, while the bridging $\mathrm{CH}_{2}$ shows a singlet at $\delta=3.66 \mathrm{ppm}$. The four equivalent isopropyl groups exhibit a set of two signals at $\delta=2.97$ and $1.01 \mathrm{ppm}$ as an septet and a doublet, respectively. The X-ray structures of $\mathbf{1 8}$ and $\mathbf{1 9}$ are presented in Figure 3, showing a $\mathrm{C} 2$ symmetric conformation (half a molecule is present in each asymmetric unit).

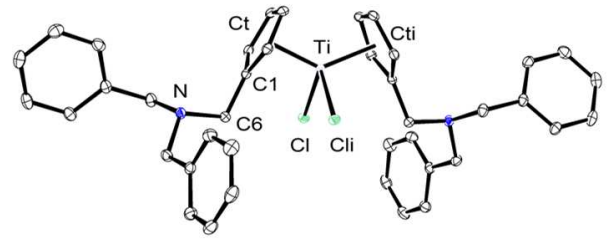

18

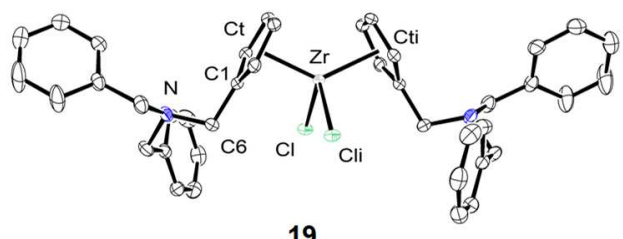

19

Figure 3. ORTEP views of complexes 18 and $\mathbf{1 9}$ (hydrogen atoms removed for clarity). Selected bond lengths $(\AA \AA)$ and angles $\left({ }^{\circ}\right): 18: \mathrm{Ti}-\mathrm{Cl}=2.3586(4), \mathrm{Ti}-\mathrm{Ct}=$ 2.0633(6), $\mathrm{Cl}-\mathrm{Ti}-\mathrm{Cl}=94.37(2), \mathrm{Ct}-\mathrm{Ti}-\mathrm{Ct}=133.01(3), \omega=0.93(4), \phi=170.4(1)$. 19: $\mathrm{Zr}-\mathrm{Cl}=2.4468(4), \mathrm{Zr}-\mathrm{Ct}=2.2058(8), \mathrm{C} 1-\mathrm{C} 6=1.504(2), \mathrm{C} 6-\mathrm{N}=1.475(2)$, $\mathrm{Cl}-\mathrm{Zr}-\mathrm{Cl}=96.42(2), \mathrm{Ct}-\mathrm{Zr}-\mathrm{Ct}=130.08(3), \omega=-9.91(5), \phi=-160.34(11)$.

The two amine moieties of $\mathbf{1 8}$ are located close to the bisecting plane of the bent metallocene $\left(\omega=0.93(4)^{\circ}\right)$ and oriented away from each other in an antiperiplanar-conformation $\left(\phi=170.4(1)^{\circ}\right)$. A slight difference in the position of the amine moiety is noted for $\left.19\left(\omega=-9.91(5)^{\circ}\right), \phi=-160.34(11)^{\circ}\right)$.

Having succeeded in installing tertiary amines close to the metallocenyl moiety, we next envisioned analogous halfsandwich titanium complexes. Indeed, we wondered whether these would show an interaction between the titanium center and the amine. All attempts at forming such complexes failed except for the synthesis of TMP complex 22 (Scheme 5). In this case, metalation was carried out with $\mathrm{TiCl}_{4}$ on the mixture of silylated fulvenes 21, readily prepared from $\mathbf{5}$ and TMSCI. Complex $\mathbf{2 2}$ was obtained in $74 \%$ yield and fully characterized. The ${ }^{1} \mathrm{H}$ NMR spectrum has roughly the same aspect as the one from 5 . The Cp' signals are shifted downfield to 6.40 and $6.15 \mathrm{ppm}$. The signal of the bridging $\mathrm{CH}_{2}$ appears as a singlet at $3.75 \mathrm{ppm}$, while the $\mathrm{CH}_{2}$ groups of the TMP ring resonate as multiplets centered at $\delta=1.26$ and $1.36 \mathrm{ppm}$. The methyl groups of the TMP moiety resonate as a singlet at $\delta=0.82 \mathrm{ppm}$, which argues against the presence of a Ti-N interaction in solution. Consistently, the $\mathrm{N}$ atom of 22 resonates at $-308 \mathrm{ppm}$ (established by ${ }^{1} \mathrm{H}{ }^{15} \mathrm{~N}$ HMBC), a value which is very close to the one observed for complex 11..$^{[14]}$ 


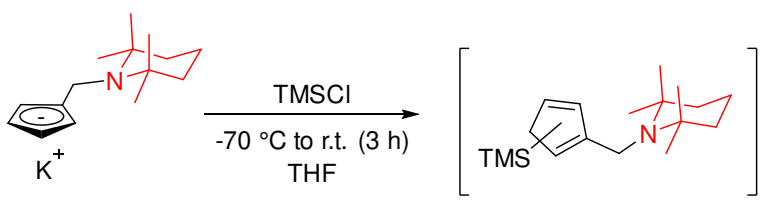

5 21

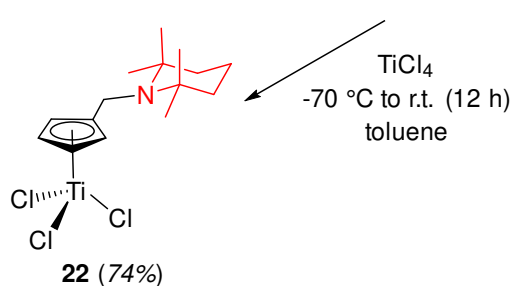

Scheme 5. Synthesis of the half-sandwich titanium complex 22.

The solid-state structure of 22 (Figure 4) shows a typical pseudotetrahedral geometry for the titanium center (piano stool-like structure), and corroborated the absence of Ti-N interaction previously inferred from solution ${ }^{1} \mathrm{H}$ NMR spectroscopy. The torsion angle $\phi$ defined above is equal to $107.03(11)^{\circ}$ indicating that the tetramethylpiperidine moiety remains tilted toward the Cp' ring as in the structures of $\mathbf{1 1}$ and $\mathbf{1 2}$. To the best of our knowledge, this is the first example of a trichlorido aminomethylcyclopentadienyl half-sandwich titanium complex. Precedents with longer alkyl spacers and less bulky amines have been described. ${ }^{[1 \mathrm{a}, 3 \mathrm{c}, 7 \mathrm{~g}, 16]}$ In most of these complexes, intra- or intermolecular coordination of the amine to Ti was observed.

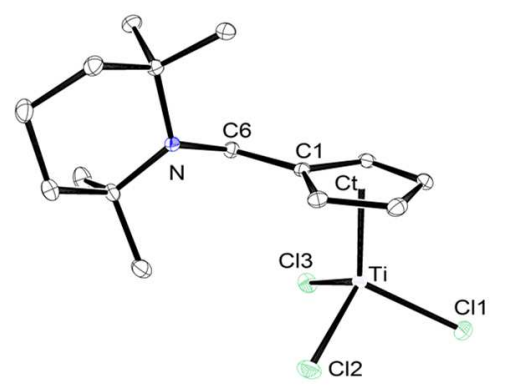

Figure 4. ORTEP view of 22 (hydrogen atoms removed for clarity). Selected bond lengths $(\AA)$ and angles $\left({ }^{\circ}\right): \mathrm{Ct}-\mathrm{Ti}=2.0162(10), \mathrm{Cl} 1-\mathrm{Ti}=2.2360(6), \mathrm{Cl} 2-\mathrm{Ti}=$ 2.2308(6), $\mathrm{Cl} 3-\mathrm{Ti}=2.2425(6), \mathrm{C} 1-\mathrm{C} 6=1.519(3), \mathrm{C} 6-\mathrm{N}=1.461(2), \mathrm{Ct}-\mathrm{Ti}-\mathrm{Cl} 1=$ 116.78(3), Ct-Ti-Cl2 = 115.36(3), Ct-Ti-Cl3 = 113.27(3), Cl1-Ti-Cl2 = 100.32(3), $\mathrm{Cl} 1-\mathrm{Ti}-\mathrm{Cl} 3=102.32(3), \mathrm{Cl} 2-\mathrm{Ti}-\mathrm{Cl} 3=106.94(3), \phi=107.03(11)$.

\section{Conclusions}

In summary, we have described the synthesis of new (aminomethyl)cyclopentadienide salts via the nucleophilic substitution of sodium cyclopentadienide on Katritzky's (benzotriazolyl) derivatives. These ligands can be coordinated to $\mathrm{Ti}$ and $\mathrm{Zr}$, yielding early metallocene complexes with a pendant tertiary amine arms. The absence of interactions between the Lewis acidic metal center and the Lewis basic $\mathrm{N}$ atom in all of the prepared complexes suggests that these new ligands could be used in organometallic frustrated Lewis pairs. ${ }^{[17]}$

\section{Experimental Section}

General considerations. All reactions were carried out under an atmosphere of Ar using Schlenk techniques or an Ar glovebox. Alumina (Brockman grade II) and $3 \AA$ molecular sieves were activated by heating for at least 6 hours above $230^{\circ} \mathrm{C}$ under vacuum $\left(<10^{-1} \mathrm{mbar}\right)$, and stored in the glovebox in order to be used as drying agents (see below). Dichloromethane, diethyl ether, pentane, tetrahydrofuran and toluene were dried using a solvent purification system (MBraun SPS-800) whilst acetonitrile, benzonitrile, bromobenzene, chlorobenzene, and heptane were distilled over $\mathrm{CaH}_{2}$ and stored over activate $3 \AA$ molecular sieves under Ar. Deuterated solvents were dried by passage through a short column of activated neutral alumina and stored over activated molecular sieves in the glovebox, either at room temperature $\left(\mathrm{C}_{6} \mathrm{D}_{6}, \mathrm{C}_{6} \mathrm{D}_{5} \mathrm{Br}, \mathrm{d}_{6}\right.$ DMSO) or at $-18^{\circ} \mathrm{C}\left(\mathrm{d}_{8}-\mathrm{THF}, \mathrm{CD}_{2} \mathrm{Cl}_{2}, \mathrm{CDCl}_{3}, \mathrm{CD}_{3} \mathrm{CN}\right)$. Chlorotrimethylsilane was distilled under atmospheric pressure before use. The following chemicals $\mathrm{CpNa}^{\left[{ }^{18]}\right.} \mathrm{TiCl}_{4}(\mathrm{THF})_{2},{ }^{[19]} \mathrm{ZrCl}_{4}(\mathrm{THF})_{2},{ }^{[19]}$ $\mathrm{CpTiCl}_{3},{ }^{[20]} \mathrm{Cp}^{*} \mathrm{TiCl}_{3},{ }^{[21]}$ and the $\mathrm{N}$-benzotriazolylmethyl-amine derivatives ${ }^{[13]}$ were synthesized according to literature procedures. $\mathrm{CpZrCl}_{3}$ was sublimed $\left(1.9 \times 10^{-2}\right.$ mbar, $\left.170^{\circ} \mathrm{C}\right)$. All other reagents were commercially available and used as received or purified according to the purification guide of laboratory chemicals if required. ${ }^{[22]}$

All of the analyses were performed at the "Plateforme d'Analyses Chimiques et de Synthèse Moléculaire de l'Université de Bourgogne". The identity and purity (> 95\%) of the complexes were unambiguously established using elemental analysis, high-resolution mass spectrometry (Electrospray lonization), NMR and IR spectroscopy. Elemental analyses were obtained on a Flash EA 1112 CHNS-O Thermo Electron Flash instrument. Exact masses of the isolated compounds were obtained on a Bruker micrOTOF-Q ESI-MS. ${ }^{1} \mathrm{H}(300.13,500.03$, or $600.23 \mathrm{MHz}),{ }^{11} \mathrm{~B}$ $(160.42 \mathrm{MHz}),{ }^{13} \mathrm{C}(125.77$ or $150.94 \mathrm{MHz}),{ }^{15} \mathrm{~N}(43.3 \mathrm{MHz})$ and ${ }^{19} \mathrm{~F}$ (470.45 MHz) NMR spectra were recorded on Bruker 300 Avance III, 500 Avance III, or 600 Avance II spectrometers. Chemical shifts are quoted in parts per million $(\delta)$ relative to TMS $\left({ }^{1} \mathrm{H}\right.$ and ${ }^{13} \mathrm{C}$ ), or $\mathrm{CH}_{3} \mathrm{NO}_{2}$ (for $\left.{ }^{15} \mathrm{~N}\right)$. IR spectra were recorded on a FT BRUKER Vertex 70v spectrophotometer (Globar MIR and $\mathrm{Hg}$ FIR sources, Ge/KBr (MIR) and silicium (FIR) beamsplitters and $\mathrm{Ge} / \mathrm{KBr}(\mathrm{MIR})$ and silicium (FIR) detectors).

X-Ray experimental procedure. Suitable crystals for X-ray analysis were selected and mounted on a mylar loop with oil on either a Bruker APEX-II CCD or on a Bruker D8 VENTURE diffractometer. Crystals were kept at $115 \mathrm{~K}$ or at $100 \mathrm{~K}$ during data collections. The structures were solved by direct methods using SIR2004,,23] ShelXS ${ }^{[24]}$ or ShelXT ${ }^{[25]}$ structure solution programs and refined with the ShelXL[26] refinement package using Least Squares minimization against $|F|^{2}$ with the aid of Olex2 program. ${ }^{[27]}$ The structure of 9 was refined as a 2-component twin with the twin law $(-1.0,0.0,0.0,0.0,-1.0,0.01 .0,0.0,1.0)$, BASF $0.3909(5)$ in $\mathrm{P} 22_{1} / \mathrm{c}$. The structure of $\mathbf{1 4}$ is slightly disordered: two positions for the $\mathrm{CHCl}_{3}$ solvate molecule, the pyrrolidine ring and the $\mathrm{Cp}$ ring were refined ( $\mathrm{Cp}$ ring as rigid group). The structure of $\mathbf{1 7}$ is also disordered, the $\mathrm{TiCl}_{2} \mathrm{Cp}$ fragment occupies two positions with a multiplicities of $0.5 / 0.5$. Two different conformations are thus obtained. The disordered $\mathrm{Cp}$ rings were also refined as rigid groups.

CCDC 1825458-1825467 contain the Supporting crystallographic data for this paper. These data can be obtained free of charge via www.ccdc.cam.ac.uk/data_request/cif, or by emailing data request@ccdc.cam.ac.uk, or by contacting The Cambridge 
Crystallographic Data Centre, 12 Union Road, Cambridge CB2 1EZ, UK: fax: +44 1223336033 .

Representative procedure for the synthesis of 1-5: To a suspension of $\mathrm{CpNa}\left(2.6 \mathrm{~g}, 0.024 \mathrm{~mol}, 1.2 \mathrm{eq}\right.$.) in $50 \mathrm{~mL}$ of $\mathrm{Et}_{2} \mathrm{O}$, was added dropwise by cannulation at $-15^{\circ} \mathrm{C}$, an etheral solution of $\mathrm{N}$-benzotriazolylmethyl-amine (0.02 mol, 1 eq.). The resulting solution was left to warm up to room temperature and then stirred for two additional hours (refluxed overnight for compounds 1 and $\mathbf{4}$ ). The white precipitate formed during the reaction was filtered off and extracted with $15 \mathrm{~mL}$ of $\mathrm{Et}_{2} \mathrm{O}$. The yellow filtrate was washed twice with $30 \mathrm{~mL}$ of deionized water. The combined organic phases were washed with a solution of saturated brine $(30 \mathrm{~mL})$ and dried over $\mathrm{MgSO}_{4}$. After filtration and careful evaporation of the solvent, the yellow oil was dissolved in pentane $(40 \mathrm{~mL})$ and left 10 min during which time the residual starting material precipitated. After filtration and careful $\left(25^{\circ} \mathrm{C}\right.$, mild depression) evaporation the corresponding diene was obtained as yellow oil. This unstable compound was directly used after dissolving in $50 \mathrm{~mL}$ of $\mathrm{Et}_{2} \mathrm{O}$. The resulting solution was cooled down to $0^{\circ} \mathrm{C}$, and a freshly-prepared solution in toluene of KHMDS (0.95 eq. vs isolated diene, $20 \mathrm{~mL}$ ) was added dropwise. The cold bath was left to warm to room temperature over $5 \mathrm{~h}$. The precipitate formed during this time was filtered off, washed with $10 \mathrm{~mL}$ of cold $\mathrm{Et}_{2} \mathrm{O}, 2 \times 15 \mathrm{~mL}$ of pentane, yielding the desired compound.

Synthesis of 1 (beige powder, $1.83 \mathrm{~g}$, yield: $39 \%$ ). ${ }^{28}$ Amount of substrates/reactants: $\mathrm{CpNa}(2.09 \mathrm{~g}, 0.0238 \mathrm{~mol}, 1.2 \mathrm{eq}.) ; \mathrm{N}-$ benzotriazolylmethyl-N-methyl-1-phenylmethanamine $(5.00 \mathrm{~g}, 0.0198 \mathrm{~mol}$, 1.0 eq.); KHMDS ( $2.82 \mathrm{~g}, 0.0141 \mathrm{~mol}, 0.95$ eq.). HMRS (ESI negative mode, dimethylsulfoxide): calcd. for $\mathrm{C}_{14} \mathrm{H}_{16} \mathrm{~N}[\mathrm{M}-\mathrm{K}]^{-}$198.12869; found 198.12773 (Rel. ab.: $100 \%,-0.7$ ppm). ${ }^{1} \mathrm{H}$ NMR $(600.23 \mathrm{MHz}, 300 \mathrm{~K}$, tetrahydrofuran- $\left.\mathrm{d}_{8}\right): \delta^{1} \mathrm{H}: 7.31(\mathrm{~m}, 2 \mathrm{H}, \mathrm{o}-\mathrm{Ph}), 7.23(\mathrm{~m}, 2 \mathrm{H}, \mathrm{m}-\mathrm{Ph}), 7.13(\mathrm{~m}$, $1 \mathrm{H}, p-\mathrm{Ph}) 5.47\left(\mathrm{~m}, 2 \mathrm{H}, \mathrm{H} 2\right.$ of $\left.\mathrm{Cp}^{\prime}\right), 5.45\left(2 \mathrm{H}, \mathrm{H3}\right.$ of $\left.\mathrm{Cp}^{\prime}\right), 3.46(\mathrm{~s}, 2 \mathrm{H}$, $\left.\mathrm{NCH}_{2} \mathrm{Ph}\right), 3.30\left(\mathrm{~s}, 2 \mathrm{H}, \mathrm{NCH}_{2} \mathrm{C}_{5} \mathrm{H}_{4}\right), 2.09\left(\mathrm{~s}, 3 \mathrm{H}, \mathrm{NCH}_{3}\right) .{ }^{13} \mathrm{C}\left\{{ }^{1} \mathrm{H}\right\} \mathrm{NMR}$ (150.94 MHz, $300 \mathrm{~K}$, tetrahydrofuran- $\left.\mathrm{d}_{8}\right): \delta^{13} \mathrm{C}: 142.2(i-\mathrm{Ph}), 129.8(o-\mathrm{Ph})$, $128.8(m-\mathrm{Ph}), 127.1(p-\mathrm{Ph}), 117.6$ ( $\left.i-\mathrm{Cp}^{\prime}\right), 106.5$ (C2 of $\left.C p^{\prime}\right), 104.9$ (C3 of $\mathrm{Cp}), 63.5\left(\mathrm{NCH}_{2} \mathrm{Ph}\right), 59.8\left(\mathrm{NCH}_{2} \mathrm{C}_{5} \mathrm{H}_{4}\right), 43.0\left(\mathrm{NCH}_{3}\right)$.

Synthesis of 2 (beige powder, $6.80 \mathrm{~g}$, yield: $74 \%$ ).[28] Amount of substrates/reactants: $\mathrm{CpNa}(5.30 \mathrm{~g}, 0.0602 \mathrm{~mol}, 1.2 \mathrm{eq}.) ; \mathrm{N}-$ benzotriazolylmethyl-pyrrolidine ( $10.0 \mathrm{~g}, 0.0494 \mathrm{~mol}, 1$ eq.); KHMDS (7.60 $\mathrm{g}, 0.0381 \mathrm{~mol}, 0.98$ eq.). HMRS (ESI negative mode, dimethylsulfoxide): calcd. For $\mathrm{C}_{10} \mathrm{H}_{14} \mathrm{~N}$ [M-K] 148.11325 ; found 148.11323 (Rel. ab.: 100\%, $0.5 \mathrm{ppm}) .{ }^{1} \mathrm{H}$ NMR $\left(600.23 \mathrm{MHz}, 300 \mathrm{~K}\right.$, dimethylsulfoxide- $\left.\mathrm{d}_{6}\right): \delta^{1} \mathrm{H}: 5.27$ (m, $2 \mathrm{H}, \mathrm{H} 2$ of $\left.\mathrm{Cp}^{\prime}\right), 5.22\left(\mathrm{~m}, 2 \mathrm{H}, \mathrm{H} 3\right.$ of $\left.\mathrm{Cp}^{\prime}\right), 3.34\left(\mathrm{~s}, 2 \mathrm{H}, \mathrm{NCH}_{2} \mathrm{C}_{5} \mathrm{H}_{4}\right), 2.36$ (m, $\left.4 \mathrm{H}, \mathrm{NCH}_{2} \mathrm{CH}_{2}\right), 1.57\left(\mathrm{~m}, 4 \mathrm{H}, \mathrm{NCH}_{2} \mathrm{CH}_{2}\right) .{ }^{13} \mathrm{C}\left\{{ }^{1} \mathrm{H}\right\} \mathrm{NMR}(150.94 \mathrm{MHz}$, $300 \mathrm{~K}$, dimethylsulfoxide- $\left.\mathrm{d}_{6}\right): \delta^{13} \mathrm{C}: 115.4$ (i-Cp'), 104.5 (C2 of $\left.\mathrm{Cp}^{\prime}\right), 102.3$ (C3 of $\left.\mathrm{Cp}^{\prime}\right), 57.2\left(\mathrm{NCH}_{2} \mathrm{C}_{5} \mathrm{H}_{4}\right), 53.2\left(\mathrm{NCH}_{2} \mathrm{CH}_{2}\right), 23.1\left(\mathrm{NCH}_{2} \mathrm{CH}_{2}\right)$.

Synthesis of 3 (beige powder, $4.80 \mathrm{~g}$, yield 67\%).[28] Amount of substrates/reactants: CpNa $(3.80 \mathrm{~g}, 0.0431 \mathrm{~mol}, 1.3 \mathrm{eq}.) ; \mathrm{N}$ benzotriazolylmethyl-N,N-diisopropylamine $(7.70 \mathrm{~g}, 0.0331 \mathrm{~mol}, 1.0 \mathrm{eq}$.). KHMDS (4.80 g, $0.0242 \mathrm{~mol}, 0.98$ eq.). HMRS (ESI negative mode,

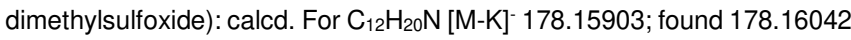
(Rel. ab.: $30 \%, 1.7 \mathrm{ppm}) .{ }^{1} \mathrm{H}$ NMR $(600.23 \mathrm{MHz}, 300 \mathrm{~K}$, dimethylsulfoxide$\left.\mathrm{d}_{6}\right): \delta^{1} \mathrm{H}: 5.28\left(\mathrm{~m}, 2 \mathrm{H}, \mathrm{H}_{2}\right.$ of $\left.\mathrm{Cp}^{\prime}\right), 5.22\left(\mathrm{~m}, 2 \mathrm{H}, H 3\right.$ of $\left.\mathrm{Cp}^{\prime}\right), 3.41(\mathrm{~s}, 2 \mathrm{H}$, $\left.\mathrm{NCH}_{2} \mathrm{C}_{5} \mathrm{H}_{4}\right), 3.21\left(\mathrm{sept},{ }^{3} \mathrm{HHH}_{\mathrm{HH}}=6.5 \mathrm{~Hz}, 2 \mathrm{H}, \mathrm{NCH}\right), 0.94\left(\mathrm{~d}, 12 \mathrm{H},{ }^{3} \mathrm{JHH}_{\mathrm{HH}}=6.5\right.$ $\left.\mathrm{Hz}, \mathrm{NCHCH}_{3}\right) .{ }^{13} \mathrm{C}\left\{{ }^{1} \mathrm{H}\right\} \mathrm{NMR}\left(150.94 \mathrm{MHz}, 300 \mathrm{~K}\right.$, dimethylsulfoxide- $\left.\mathrm{d}_{6}\right)$ : $\delta^{13} \mathrm{C}: 116.8$ (i-Cp'), 104.0 (C2 of $\left.\mathrm{Cp}^{\prime}\right), 102.2$ (C3 of $\left.\mathrm{Cp}^{\prime}\right), 44.9(\mathrm{NCH}), 44.6$ $\left(\mathrm{NCH}_{2} \mathrm{C}_{5} \mathrm{H}_{4}\right), 20.7\left(\mathrm{NCHCH}_{3}\right)$.

Synthesis of 4 (brown powder, $8.52 \mathrm{~g}$, overall yield: 60\%). ${ }^{[28]}$ Amount of substrates/reactants: $\mathrm{CpNa}(6.00 \mathrm{~g}, 0.0547 \mathrm{~mol}, 1.2 \mathrm{eq}$ ); $\mathrm{N}$ benzotriazolylmethyl-N-benzyl-1-phenylmethanamine $(15 \mathrm{~g}, 0.0457 \mathrm{~mol}$, 1.0 eq.); KHMDS (5.77 g, 0.0289 mol, 0.90 eq.). HMRS (ESI negative mode, dimethylsulfoxide): calcd. For $\mathrm{C}_{20} \mathrm{H}_{20} \mathrm{~N}$ [M-K] 274.15903; found 274.15967 (Rel. ab.: 5\%, -1.7 ppm). ${ }^{1} \mathrm{H}$ NMR $(500.13 \mathrm{MHz}, 300 \mathrm{~K}$, dimethylsulfoxide- $\left.\mathrm{d}_{6}\right): \delta^{1} \mathrm{H}: 7.41$ (m, $\left.4 \mathrm{H}, o-\mathrm{Ph}\right), 7.29(\mathrm{~m}, 4 \mathrm{H}, \mathrm{m}-\mathrm{Ph}), 7.17$ (m, 2H, p-Ph) 5.42 (m, 2H, H2 of Cp'), 5.32 (m, 2H, $H 3$ of $\left.\mathrm{Cp}^{\prime}\right), 3.53$ (s, 4H, $\left.\mathrm{NCH}_{2} \mathrm{Ph}\right), 3.40\left(\mathrm{~s}, 2 \mathrm{H}, \mathrm{NCH}_{2} \mathrm{C}_{5} \mathrm{H}_{4}\right) .{ }^{13} \mathrm{C}\left\{{ }^{1} \mathrm{H}\right\} \mathrm{NMR}(125.77 \mathrm{MHz}, 300 \mathrm{~K}$ dimethylsulfoxide- $\left.\mathrm{d}_{6}\right): \delta^{13} \mathrm{C}: 142.0(i-\mathrm{Ph}), 128.8(o-\mathrm{Ph}), 128.2(m-\mathrm{Ph})$, $126.4(p-\mathrm{Ph}), 114.0$ (i-Cp'), 105.6 (C2 of $\left.\mathrm{Cp}^{\prime}\right), 103.3$ (C3 of $\left.\mathrm{Cp}^{\prime}\right), 57.0$ $\left(\mathrm{NCH}_{2} \mathrm{Ph}\right), 55.1\left(\mathrm{NCH}_{2} \mathrm{C}_{5} \mathrm{H}_{4}\right)$.

Synthesis of 5 (beige powder, $12.0 \mathrm{~g}$, yield 86\%).[28] Amount of substrates/reactants: $\mathrm{CpNa}\left(0.0682 \mathrm{~mol}, \begin{array}{lll}1.36 & \text { eq. }) ; \quad \mathrm{N}-\end{array}\right.$ benzotriazolylmethyl-2,2,6,6-tetramethylpiperidine $(13.8 \mathrm{~g}, 0.0507 \mathrm{~mol}$, 1.0 eq.); KHMDS (8.85 g, $0.0444 \mathrm{~mol}, 0.99$ eq.). HMRS (ESI negative mode, dimethylsulfoxide): calcd. For $\mathrm{C}_{15} \mathrm{H}_{24} \mathrm{~N}$ [M-K] 218.19033; found 218.19111 (Rel. ab.: $100 \%,-1.4$ ppm). ${ }^{1} \mathrm{H}$ NMR $(600.23 \mathrm{MHz}, 300 \mathrm{~K}$, tetrahydrofuran-d8): $\delta^{1} \mathrm{H}: 5.46\left(\mathrm{~m}, 2 \mathrm{H}, \mathrm{H} 2\right.$ of $\left.\mathrm{Cp}^{\prime}\right), 5.38\left(\mathrm{~m}, 2 \mathrm{H}, \mathrm{H} 3\right.$ of $\left.\mathrm{Cp}^{\prime}\right)$, $3.55\left(\mathrm{~s}, 2 \mathrm{H}, \mathrm{NCH}_{2} \mathrm{C}_{5} \mathrm{H}_{4}\right), 1.57\left(\mathrm{~m}, 2 \mathrm{H}, \mathrm{NC}\left(\mathrm{CH}_{3}\right)_{2} \mathrm{CH}_{2} \mathrm{CH}_{2}\right), 1.43(\mathrm{~m}, 4 \mathrm{H}$, $\left.\mathrm{NC}\left(\mathrm{CH}_{3}\right)_{2} \mathrm{CH}_{2}\right), 1.12\left(\mathrm{~s}, 12 \mathrm{H}, \mathrm{NC}\left(\mathrm{CH}_{3}\right)_{2}\right) \cdot{ }^{13} \mathrm{C}\left\{{ }^{1} \mathrm{H}\right\} \mathrm{NMR}(150.94 \mathrm{MHz}, 300$ $\mathrm{K}$, tetrahydrofuran- $\left.\mathrm{d}_{8}\right): \delta^{13} \mathrm{C}: 123.5\left(i-\mathrm{Cp}^{\prime}\right), 105.6\left(C 2\right.$ of $\left.\mathrm{Cp}^{\prime}\right), 104.1$ (C3 of $\left.\mathrm{Cp}^{\prime}\right), 55.6\left(\mathrm{NC}\left(\mathrm{CH}_{3}\right)_{2}\right), 45.0\left(\mathrm{NCH}_{2} \mathrm{C}_{5} \mathrm{H}_{4}\right), 42.9\left(\mathrm{NC}\left(\mathrm{CH}_{3}\right)_{2} \mathrm{CH}_{2}\right), 29.0$ $\left(\mathrm{NC}\left(\mathrm{CH}_{3}\right)_{2}\right), 19.2\left(\mathrm{NC}\left(\mathrm{CH}_{3}\right)_{2} \mathrm{CH}_{2} \mathrm{CH}_{2}\right)$.

General procedure for the synthesis of 6-11: A solution of sodium (aminomethyl)cyclopentadienide $(0.818 \mathrm{~g}, 0.0034 \mathrm{~mol}, 1.05$ eq.) in $25 \mathrm{~mL}$ of THF was added to a solution of $\mathrm{CpTiCl}_{3}(0.718 \mathrm{~g}, 0.0032 \mathrm{~mol}, 1.0 \mathrm{eq}$.) in $20 \mathrm{~mL}$ of toluene, by cannulation at $-30^{\circ} \mathrm{C}$. The resulting solution was left to warm up to room temperature and then stirred overnight. The crude red solution was first evaporated. The deep red oil obtained was dissolved in $20 \mathrm{~mL}$ of $\mathrm{CH}_{2} \mathrm{Cl}_{2}$, filtered through diatomaceous earth, which was then washed by $2 \times 5 \mathrm{~mL}$ of $\mathrm{CH}_{2} \mathrm{Cl}_{2}$. The deep red extracts obtained were concentrated by evaporation of $3 / 4$ of the solvent and the compound was precipitate by addition of pentane with vigorous stirring. The orange-red precipitate was filtered off, and dried to yield the desired compound.

Synthesis of 6 (orange-red powder, $0.680 \mathrm{~g}$, yield $=54 \%$ ). Amount of substrates/reactants: 1 (0.818 g, $0.0034 \mathrm{~mol}, 1.05$ eq.); $\mathrm{CpTiCl}_{3}$ (718 mg, $0.0032 \mathrm{~mol}, 1.0$ eq.). HMRS (Positive mode ESI, dichloromethane): $\mathrm{m} / \mathrm{z}$ calcd. for $\mathrm{C}_{19} \mathrm{H}_{21} \mathrm{NCITi}[\mathrm{M}-\mathrm{Cl}]^{+} 346.08388$; found 346.08446 (Rel. ab.: $90 \%$, $2.3 \mathrm{ppm}$ ). Elemental Analysis: \% calcd for $\mathrm{C}_{19} \mathrm{H}_{19} \mathrm{NCl}_{2} \mathrm{Ti}: \mathrm{C}, 59.72 ; \mathrm{H}, 5.54$; $\mathrm{N}, 3.67$; Found: C, 58.93; H, 5.50; N, 3.58. ${ }^{1} \mathrm{H}$ NMR $(600.23 \mathrm{MHz}, 300 \mathrm{~K}$, benzene- $\left.\mathrm{d}_{6}\right): \delta^{1} \mathrm{H}: 7.29(\mathrm{~m}, 2 \mathrm{H}, o-\mathrm{Ph}), 7.18(\mathrm{~m}, 2 \mathrm{H}, m-\mathrm{Ph}), 7.10(\mathrm{~m}, 1 \mathrm{H}, p-$ $\mathrm{Ph}) 6.26\left(\mathrm{~m}, 2 \mathrm{H}, \mathrm{H} 2\right.$ of $\left.\mathrm{Cp}^{\prime}\right), 5.98(\mathrm{~s}, 5 \mathrm{H}, \mathrm{Cp}), 5.68$ (m, 2H, $H 3$ of $\left.\mathrm{Cp}^{\prime}\right), 3.74$ (s, $\left.2 \mathrm{H}, \mathrm{NCH}_{2} \mathrm{C}_{5} \mathrm{H}_{4}\right), 3.33\left(\mathrm{~s}, 2 \mathrm{H}, \mathrm{NCH}_{2} \mathrm{Ph}\right), 2.02\left(\mathrm{~s}, 3 \mathrm{H}, \mathrm{NCH}_{3}\right) .{ }^{13} \mathrm{C}\left\{{ }^{1} \mathrm{H}\right\}$ NMR (125.77 MHz, $300 \mathrm{~K}$, benzene- $\left.\mathrm{d}_{6}\right): \delta^{13} \mathrm{C}: 139.6(i-\mathrm{Ph}), 133.2\left(i-\mathrm{Cp} \mathrm{p}^{\prime}\right)$, 129.3 (o-Ph), $128.6(m-\mathrm{Ph}), 127.4$ ( $p-\mathrm{Ph}), 124.6$ (C2 of $\left.C p^{\prime}\right), 119.5(\mathrm{Cp})$, 115.1 (C3 of $\left.\mathrm{Cp}^{\prime}\right), 62.1\left(\mathrm{NCH}_{2} \mathrm{Ph}\right), 57.7\left(\mathrm{NCH}_{2} \mathrm{C}_{5} \mathrm{H}_{4}\right), 42.2\left(\mathrm{NCH}_{3}\right)$.

Synthesis of 7 (orange-red powder, $2.74 \mathrm{~g}$, yield = $69 \%$ ). Amount of substrates/reactants: 2 (2.25 g, 0.0120 mol, 1.05 eq.); $\mathrm{CpTiCl}_{3}$ (2.51 g, $0.0114 \mathrm{~mol}, 1.0$ eq.). HMRS (Positive mode ESI, dichloromethane): $\mathrm{m} / \mathrm{z}$ calcd. for $\mathrm{C}_{15} \mathrm{H}_{19} \mathrm{NCITi}[\mathrm{M}-\mathrm{Cl}]^{+} 296.06717$; found 296.06819 (Rel. ab.: 50\%, $-2.8 \mathrm{ppm}$ ). Elemental Analysis: \% calcd for $\mathrm{C}_{15} \mathrm{H}_{19} \mathrm{NCl}_{2} \mathrm{Ti}: \mathrm{C}, 54.25 ; \mathrm{H}, 5.77$; $\mathrm{N}, 4.22$; Found: C, 54.66; H, 5.51; N, 4.26. ${ }^{1} \mathrm{H}$ NMR $(600 \mathrm{MHz}, 300 \mathrm{~K}$, dichloromethane- $\mathrm{d}_{2}$ ): $\delta^{1} \mathrm{H}: 6.57$ (s, $\left.5 \mathrm{H}, \mathrm{Cp}\right), 6.52\left(\mathrm{~m}, 2 \mathrm{H}, \mathrm{H2}\right.$ of $\left.\mathrm{Cp}^{\prime}\right), 6.46$ (m, $2 \mathrm{H}, H 3$ of $\mathrm{Cp}^{\prime}$ ), 3.67 (s, $\left.2 \mathrm{H}, \mathrm{NCH}_{2} \mathrm{C}_{5} \mathrm{H}_{4}\right), 2.55$ (broad, $4 \mathrm{H}, \mathrm{NCH}_{2} \mathrm{CH}_{2}$ ), 1.77 (broad, $\left.4 \mathrm{H}, \mathrm{NCH}_{2} \mathrm{CH}_{2}\right) .{ }^{13} \mathrm{C}\left\{{ }^{1} \mathrm{H}\right\}$ NMR $(150.94 \mathrm{MHz}, 300 \mathrm{~K}$, dichloromethane- $\mathrm{d}_{2}$ ): $\delta^{13} \mathrm{C}: 133.9$ (i-Cp'), 124.7 (C2 of $\left.\mathrm{Cp}^{\prime}\right), 120.6(\mathrm{Cp})$, 116.8 (C3 of $\left.\mathrm{Cp}^{\prime}\right), 55.8\left(\mathrm{NCH}_{2} \mathrm{C}_{5} \mathrm{H}_{4}\right), 54.7\left(\mathrm{NCH}_{2} \mathrm{CH}_{2}\right), 24.1\left(\mathrm{NCH}_{2} \mathrm{CH}_{2}\right)$.

Synthesis of 8 (orange-red powder, $1.61 \mathrm{~g}$, yield $=80 \%$ ). Amount of substrates/reactants: 3 (1.19 g, $0.0055 \mathrm{~mol}, 1.05$ eq.); $\mathrm{CpTiCl}_{3}(1.14 \mathrm{~g}$, $0.0052 \mathrm{~mol}, 1.0$ eq.). HMRS (Positive mode ESI, dichloromethane): $\mathrm{m} / \mathrm{z}$ calcd. for $\mathrm{C}_{17} \mathrm{H}_{26} \mathrm{NClTi}[\mathrm{M}+\mathrm{H}]^{+}$362.09189; found 362.09285 (Rel. ab.: $100 \%, 3.4$ ppm). Elemental Analysis: \% calcd for $\mathrm{C}_{17} \mathrm{H}_{25} \mathrm{Cl}_{2} \mathrm{NTi}$ : C, 56.38; 
$\mathrm{H}, 6.96$; N, 3.87; Found: C, 55.99; H, 6.96; N, 3.88. ${ }^{1} \mathrm{H}$ NMR $(600.23 \mathrm{MHz}$ $300 \mathrm{~K}$, dichloromethane- $\left.\mathrm{d}_{2}\right): \delta^{1} \mathrm{H}: 6.54(\mathrm{~s}, 5 \mathrm{H}, \mathrm{Cp}), 6.52(\mathrm{~m}, 2 \mathrm{H}, \mathrm{H} 2 \text { of } \mathrm{Cp})^{\prime}$, $6.44\left(\mathrm{~m}, 2 \mathrm{H}, \mathrm{H} 3\right.$ of $\left.\mathrm{Cp}^{\prime}\right), 3.71$ (s, $2 \mathrm{H}, \mathrm{NCH}_{2} \mathrm{Cp}$ ), 2.97 (sept, ${ }^{3} \mathrm{JHH}_{\mathrm{HH}} 6.6 \mathrm{~Hz}$, $2 \mathrm{H}, \mathrm{NCH}), 1.01\left(\mathrm{~d},{ }^{3} \mathrm{JHH}_{\mathrm{HH}}=6.6 \mathrm{~Hz}, 12 \mathrm{H}, \mathrm{NCHCH}_{3}\right) .{ }^{13} \mathrm{C}\left\{{ }^{1} \mathrm{H}\right\} \mathrm{NMR}(150.94$ $\mathrm{MHz}, 300 \mathrm{~K}$, dichloromethane-d 2 ): $\delta^{13} \mathrm{C}: 140.4$ (i-Cp'), 124.1 (C2 of $\left.\mathrm{Cp}^{\prime}\right)$, $120.3(\mathrm{Cp}), 117.2$ (C3 of $\left.\mathrm{Cp}^{\prime}\right), 49.2(\mathrm{NCH}), 45.6\left(\mathrm{NCH}_{2} \mathrm{C}_{5} \mathrm{H}_{4}\right), 21.3$ $\left(\mathrm{NCHCH}_{3}\right)$.

Synthesis of 9 (red powder, $0.923 \mathrm{~g}$, yield $=46 \%$ ). Amount of substrates/reactants: 3 (1.00 g, $0.0046 \mathrm{~mol}, 1.05$ eq.) $\mathrm{Cp}^{*} \mathrm{TiCl}_{3}(1.27 \mathrm{~g}$, $0.0044 \mathrm{~mol}, 1.0$ eq.). HMRS (Positive mode ESI, dichloromethane): $\mathrm{m} / \mathrm{z}$ calcd. for $\mathrm{C}_{22} \mathrm{H}_{36} \mathrm{NCl}_{2} \mathrm{Ti}[\mathrm{M}+\mathrm{H}]^{+}$432.17019; found 432.16878 (Rel. ab. $100 \%,-2.5 \mathrm{ppm}$ ). Elemental Analysis: \% calcd for $\mathrm{C}_{22} \mathrm{H}_{35} \mathrm{NCl}_{2} \mathrm{Ti}$ : C, 61.12; $\mathrm{H}, 8.16$; N, 3.24; Found: C, 61.13; H, 8.26; N, 3.40. ${ }^{1} \mathrm{H} \mathrm{NMR}(600.23 \mathrm{MHz}$, $300 \mathrm{~K}$, dichloromethane- $\left.\mathrm{d}_{2}\right): \delta^{1} \mathrm{H}: 6.19\left(\mathrm{~m}, \mathrm{H2}\right.$ of $\left.\mathrm{Cp}{ }^{\prime}\right), 5.99(\mathrm{~m}, 2 \mathrm{H}, H 3$ of Cp'), $3.69\left(\mathrm{~s}, 2 \mathrm{H}, \mathrm{NCH}_{2} \mathrm{C}_{5} \mathrm{H}_{4}\right), 2.97\left(\mathrm{sept},{ }^{3} \mathrm{JHH}_{\mathrm{HH}}=6.7 \mathrm{~Hz}, 2 \mathrm{H}, \mathrm{NCH}\right), 2.01$ (s, $15 \mathrm{H}, \mathrm{CH}_{3}$ of $\left.\mathrm{Cp}^{*}\right), 1.00\left(\mathrm{~d},{ }^{3} \mathrm{HH}=6.7 \mathrm{~Hz}, 12 \mathrm{H}, \mathrm{NCHCH}_{3}\right) .{ }^{13} \mathrm{C}\left\{{ }^{1} \mathrm{H}\right\} \mathrm{NMR}$ $\left(150.94 \mathrm{MHz}, 300 \mathrm{~K}\right.$, dichloromethane- $\left.\mathrm{d}_{2}\right): \delta^{13} \mathrm{C}: 139.5\left(i-\mathrm{Cp}^{\prime}\right), 130.0(i-$ $\left.\mathrm{Cp}^{*}\right), 124.4\left(\mathrm{C2}\right.$ of $\left.\mathrm{Cp} \mathrm{p}^{\prime}\right), 115.9$ (C3 of $\left.\mathrm{Cp} \mathrm{p}^{\prime}\right), 49.1(\mathrm{NCH}), 45.4\left(\mathrm{NCH}_{2} \mathrm{C}_{5} \mathrm{H}_{4}\right)$, $21.3\left(\mathrm{NCHCH}_{3}\right), 13.8\left(\mathrm{CH}_{3}\right.$ of $\left.\mathrm{Cp}^{*}\right)$.

Synthesis of 10 (orange-red powder, $4.0 \mathrm{~g}$, yield $=80 \%$ ). Amount of substrates/reactants: 4 (3.76 g, 0.0119 mol, 1.05 eq.); $\mathrm{CpTiCl}_{3}(2.50 \mathrm{~g}$, $0.0114 \mathrm{~mol}, 1.0$ eq.). HMRS (Positive mode ESI, dichloromethane): $\mathrm{m} / \mathrm{z}$ calcd. for $\mathrm{C}_{25} \mathrm{H}_{26} \mathrm{NCl}_{2} \mathrm{Ti}[\mathrm{M}+\mathrm{H}]^{+} 458.09196$; found 458.09393 (Rel. ab.: $100 \%, 5.0$ ppm). Elemental Analysis: \% calcd: C, 65.53; H, 5.50; N, 3.06; Found: $\mathrm{C}, 66.52 ; \mathrm{H}, 5.57 ; \mathrm{N}, 3.20 .{ }^{1} \mathrm{H}$ NMR $(600.23 \mathrm{MHz}, 300 \mathrm{~K}$, dichloromethane- $\left.\mathrm{d}_{2}\right): \delta^{1} \mathrm{H}: 7.38(\mathrm{~m}, 4 \mathrm{H}, \mathrm{o}-\mathrm{Ph}), 7.33(\mathrm{~m}, 4 \mathrm{H}, \mathrm{m}-\mathrm{Ph}), 7.25(\mathrm{~m}$, $2 \mathrm{H}, p-\mathrm{Ph}), 6.52(\mathrm{~m}, 2 \mathrm{H}, \mathrm{H} 2$ of $\mathrm{Cp}$ '), $6.43(\mathrm{~m}, 2 \mathrm{H}, \mathrm{H} 3$ of $\mathrm{Cp}$ '), $6.38(\mathrm{~s}, 5 \mathrm{H}$, $\mathrm{Cp}), 3.60\left(\mathrm{~s}, 2 \mathrm{H}, \mathrm{NCH}_{2} \mathrm{C}_{5} \mathrm{H}_{4}\right), 3.57\left(\mathrm{~s}, 4 \mathrm{H}, \mathrm{NCH}_{2} \mathrm{Ph}\right) .{ }^{13} \mathrm{C}\left\{{ }^{1} \mathrm{H}\right\} \mathrm{NMR}(150.94$ $\mathrm{MHz}, 300 \mathrm{~K}$, dichloromethane- $\left.\mathrm{d}_{2}\right): \delta^{13} \mathrm{C}: 139.9$ (i-Ph), 133.5 (i-Cp'), 129.5 (o-Ph), $128.8(m-\mathrm{Ph}), 127.6$ (p-Ph), 124.5 (C2 of $\left.\mathrm{Cp}^{\prime}\right), 120.5(\mathrm{Cp}), 117.6$ (C3 of $\left.\mathrm{Cp}^{\prime}\right), 58.8\left(\mathrm{NCH}_{2} \mathrm{Ph}\right), 53.6\left(\mathrm{NCH}_{2} \mathrm{C}_{5} \mathrm{H}_{4}\right)$.

Synthesis of 11 (orange powder, $0.870 \mathrm{~g}$, yield $=68 \%$ ). Amount of substrates/reactants: 5 (0.693 g, $0.0032 \mathrm{~mol}, 1.05$ eq.); $\mathrm{CpTiCl}_{3}(0.800 \mathrm{~g}$, $0.0031 \mathrm{~mol}, 1.0$ eq.). HMRS (Positive mode ESI, dichloromethane): $\mathrm{m} / \mathrm{z}$ calcd. for $\mathrm{C}_{20} \mathrm{H}_{30} \mathrm{NCl}_{2} \mathrm{Ti}[\mathrm{M}+\mathrm{H}]+402.12322$; found 402.12089 (Rel. ab.: $90 \%,-5.1 \mathrm{ppm}$ ). Elemental Analysis: \% calcd for $\mathrm{C}_{20} \mathrm{H}_{29} \mathrm{NCl}_{2} \mathrm{Ti}$ : C, 59.72; H, 7.27; N, 3.48; Found: C, 59.88; H, 7.71; N, 3.44. ${ }^{1} \mathrm{H} \mathrm{NMR}(600.23 \mathrm{MHz}$, $300 \mathrm{~K}$, benzene- $\left.\mathrm{d}_{6}\right): \delta^{1} \mathrm{H}: 6.23$ (broad, $2 \mathrm{H}, \mathrm{H}_{2}$ of $\left.\mathrm{Cp}^{\prime}\right), 6.01$ (s, $5 \mathrm{H}, \mathrm{Cp}$ ), 5.70 (broad, $2 \mathrm{H}, \mathrm{H3}$ of $\left.\mathrm{Cp}^{\prime}\right), 4.02\left(\mathrm{~s}, 2 \mathrm{H}, \mathrm{NCH}_{2} \mathrm{C}_{5} \mathrm{H}_{4}\right), 1.43(\mathrm{~m}, 2 \mathrm{H}$, $\left.\mathrm{NC}\left(\mathrm{CH}_{3}\right)_{2} \mathrm{CH}_{2} \mathrm{CH}_{2}\right), 1.37\left(\mathrm{~m}, 4 \mathrm{H}, \mathrm{NC}\left(\mathrm{CH}_{3}\right)_{2} \mathrm{CH}_{2}\right), 1.01\left(\mathrm{~s}, 12 \mathrm{H}, \mathrm{NC}\left(\mathrm{CH}_{3}\right)_{2}\right)$. $\left.{ }^{13} \mathrm{C}^{1}{ }^{\mathrm{H}}\right\}$ NMR $\left(150.94 \mathrm{MHz}, 300 \mathrm{~K}\right.$, benzene- $\left.\mathrm{d}_{6}\right): \delta^{13} \mathrm{C}: 146.2\left(i-\mathrm{Cp}^{\prime}\right), 121.9$ (C2 of $\left.\mathrm{Cp}^{\prime}\right), 119.1$ (Cp), 115.6 (C3 of $\left.\mathrm{Cp}^{\prime}\right), 55.6\left(\mathrm{NC}\left(\mathrm{CH}_{3}\right)_{2}\right), 45.6$ $\left(\mathrm{NCH}_{2} \mathrm{C}_{5} \mathrm{H}_{4}\right), \quad 41.9 \quad\left(\mathrm{NC}\left(\mathrm{CH}_{3}\right)_{2} \mathrm{CH}_{2}\right), \quad 28.2$ (broad, $\left.\mathrm{NC}\left(\mathrm{CH}_{3}\right)_{2}\right), 18.2$ $\left(\mathrm{NC}\left(\mathrm{CH}_{3}\right)_{2} \mathrm{CH}_{2} \mathrm{CH}_{2}\right)$.

Synthesis of 12. A solution of $5(0.586 \mathrm{~g}, 0.0027 \mathrm{~mol}, 1.0 \mathrm{eq}$.) in $35 \mathrm{~mL}$ of THF was added to a solution of $\mathrm{CpZrCl}_{3}(0.700 \mathrm{~g}, 0.0027 \mathrm{~mol}, 1.0 \mathrm{eq}$.) in $35 \mathrm{~mL}$ of THF cooled down to $-30^{\circ} \mathrm{C}$. The resulting solution was left to warm up to room temperature and then stirred overnight. The crude solution was evaporated and the residue was treated with $30 \mathrm{~mL}$ of dichloromethane. After filtration through diatomaceous earth, the filtrate was evaporated and the residue triturated with $15 \mathrm{~mL}$ of pentane in order to form a white powder. The supernatant was removed and the precipitate washed twice with $5 \mathrm{~mL}$ of pentane. The desired compound was obtained after removal of all volatiles as a white powder. $(0.640 \mathrm{~g}, 54 \%){ }^{[29]} \mathrm{HMRS}$ (Positive mode ESI, dichloromethane): $\mathrm{m} / \mathrm{z}$ calcd. for $\mathrm{C}_{20} \mathrm{H}_{30} \mathrm{NCl}_{2} \mathrm{Zr}[\mathrm{M}+\mathrm{H}]^{+}$ 444.07969; found 444.07893 (Rel. ab.: $10 \%,-1.701 \mathrm{ppm}$ ), $\mathrm{C}_{15} \mathrm{H}_{26} \mathrm{~N}$ [M$\left.\mathrm{CpZrCl}_{2}+\mathrm{H}\right]^{+} 220.20652$ found 220.20539 (Rel. ab.: 100\%, $-5.1 \mathrm{ppm}$ ). ${ }^{1} \mathrm{H}$ $\operatorname{NMR}\left(600.23 \mathrm{MHz}, 300 \mathrm{~K}\right.$, tetrahydrofuran-(d8): $\delta^{1} \mathrm{H}: 6.45$ (s, 5H, Cp), 6.38 (m, $2 \mathrm{H}, \mathrm{H} 3$ of $\left.\mathrm{Cp} \mathrm{p}^{\prime}\right), 6.31$ (m, 2H, H2 of $\left.\mathrm{Cp}^{\prime}\right), 3.82\left(\mathrm{~s}, 2 \mathrm{H}, \mathrm{NCH}_{2} \mathrm{C}_{5} \mathrm{H}_{4}\right), 1.55$ (m, $\left.2 \mathrm{H}, \mathrm{NC}\left(\mathrm{CH}_{3}\right)_{2} \mathrm{CH}_{2} \mathrm{CH}_{2}\right), 1.42$ (m, 4H, NC( $\left.\left.\mathrm{CH}_{3}\right)_{2} \mathrm{CH}_{2}\right), 1.03$ (s, $12 \mathrm{H}$,
$\left.\mathrm{NC}\left(\mathrm{CH}_{3}\right)_{2}\right) .{ }^{13} \mathrm{C}\left\{{ }^{1} \mathrm{H}\right\} \mathrm{NMR}\left(150.94 \mathrm{MHz}, 300 \mathrm{~K}\right.$, tetrahydrofuran- $\left.\mathrm{d}_{8}\right): \delta^{13} \mathrm{C}$ : 142.6 (i-Cp'), 117.6 (C2 of $\left.\mathrm{Cp}^{\prime}\right), 116.6$ (Cp), 113.9 (C3 of $\left.C p^{\prime}\right), 56.2$ $\left(\mathrm{NC}\left(\mathrm{CH}_{3}\right)_{2}\right), 45.4\left(\mathrm{NCH}_{2} \mathrm{C}_{5} \mathrm{H}_{4}\right), 42.7\left(\mathrm{NC}\left(\mathrm{CH}_{3}\right)_{2} \mathrm{CH}_{2}\right), 28.6\left(\mathrm{NC}\left(\mathrm{CH}_{3}\right)_{2}\right), 18.9$ $\left(\mathrm{NC}\left(\mathrm{CH}_{3}\right)_{2} \mathrm{CH}_{2} \mathrm{CH}_{2}\right)$.

General procedure for the synthesis of 13-17. To a solution of (aminomethyl)titanocene dichloride ( $0.0003 \mathrm{~mol}, 1$ eq., $5 \mathrm{~mL}$ toluene) was added dropwise a freshly-prepared $\mathrm{HCl}$ solution ( $5 \mathrm{~mL}$ of toluene). A red precipitate was directly formed. The reaction mixture was left to stir for 15 $\mathrm{min}$. The precipitate was then filtered off and washed with $3 \times 5 \mathrm{~mL}$ of pentane under aerobic conditions, yielding the desired product.

Synthesis of 13 (red powder, $0.074 \mathrm{~g}$, yield: $67 \%$ ). Amount of substrates/reactants: 6 ( $0.100 \mathrm{~g}, 0.0003 \mathrm{~mol}, .01$ eq., $5 \mathrm{~mL}$ toluene); $5 \mathrm{~mL}$ of a HCl-saturated toluene solution. HMRS (Positive mode ESI, dichloromethane): $\mathrm{m} / \mathrm{z}$ calcd. for $\mathrm{C}_{19} \mathrm{H}_{22} \mathrm{NCl}_{2} \mathrm{Ti}[\mathrm{M}]^{+}$382.06060; found 382.05935 (Rel. ab.: 10\%, -2.6 ppm). Elemental Analysis: \% calcd for $\mathrm{C}_{19} \mathrm{H}_{22} \mathrm{Cl}_{3} \mathrm{NTi}: \mathrm{C}, 54.51 ; \mathrm{H}, 5.30 ; \mathrm{N}, 3.35$; Found: C, 54.50; H, 5.44; N, 3.69. ${ }^{1} \mathrm{H}$ NMR $\left(600.23 \mathrm{MHz}, 300 \mathrm{~K}\right.$, chloroform-d $\left.\mathrm{d}_{1}\right): \delta^{1} \mathrm{H}: 12.83$ (s, 1H, NH), 7.60 $(\mathrm{m}, 2 \mathrm{H}, o-\mathrm{Ph}), 7.46(\mathrm{~m}, 3 \mathrm{H}, \mathrm{m}$-Ph overlapping with $p-\mathrm{Ph}), 7.07\left(\mathrm{q},{ }^{3}{ }_{\mathrm{HH}}=\right.$ ${ }^{4} J_{\mathrm{HH}}=2.6 \mathrm{~Hz}, 1 \mathrm{H}, \mathrm{H} 2$ of $\mathrm{Cp}$ '), $6.97\left(\mathrm{q},{ }^{3} \mathrm{~J}_{\mathrm{HH}}={ }^{4} \mathrm{~J}_{\mathrm{HH}}=2.6 \mathrm{~Hz}, 1 \mathrm{H}, H 5\right.$ of $\mathrm{Cp}$ '), $6.69(\mathrm{~s}, 5 \mathrm{H}, \mathrm{Cp}), 6.60\left(\mathrm{q},{ }^{3} \mathrm{JHH}_{\mathrm{HH}}={ }^{4} \mathrm{JHH}=2.6 \mathrm{~Hz}, 1 \mathrm{H}, \mathrm{H3}\right.$ of $\mathrm{Cp}$ ) $) 6.57\left(\mathrm{q},{ }^{3} \mathrm{JHH}\right.$ $={ }^{4} \mathrm{JHH}=2.6 \mathrm{~Hz}, 1 \mathrm{H}, \mathrm{H} 4$ of $\mathrm{Cp}$ '), $4.38\left(\mathrm{dd},{ }^{2}{ }^{\mathrm{HH}}=13.2 \mathrm{~Hz}{ }^{3} \mathrm{JHH}=3.6 \mathrm{~Hz}, 1 \mathrm{H}\right.$, $\left.\mathrm{NCH}_{2} \mathrm{Ph}\right), 4.37\left(\mathrm{dd},{ }^{2} \mathrm{JHH}_{\mathrm{HH}} 13.7 \mathrm{~Hz}{ }^{3} \mathrm{~J}_{\mathrm{HH}}=4.6 \mathrm{~Hz}, 1 \mathrm{H}, \mathrm{NCH}_{2} \mathrm{C}_{5} \mathrm{H}_{4}\right), 4.13(\mathrm{dd}$, $\left.{ }^{2} \mathrm{JHH}_{\mathrm{HH}}=13.7 \mathrm{~Hz},{ }^{3} \mathrm{JHH}_{\mathrm{HH}}=6.0 \mathrm{~Hz}, 1 \mathrm{H}, \mathrm{NCH}_{2} \mathrm{C}_{5} \mathrm{H}_{4}\right), 4.04\left(\mathrm{dd},{ }^{2} \mathrm{JHH}_{\mathrm{HH}}=13.2 \mathrm{~Hz}\right.$, $\left.{ }^{3} \mathrm{JHH}_{\mathrm{HH}}=6.6 \mathrm{~Hz}, 1 \mathrm{H}, \mathrm{NCH}_{2} \mathrm{Ph}\right), 2.60\left(\mathrm{~d},{ }^{3} \mathrm{JHH}_{\mathrm{HH}}=2.6 \mathrm{~Hz}, 3 \mathrm{H}, \mathrm{NCH}\right) .{ }^{13} \mathrm{C}\left\{{ }^{1} \mathrm{H}\right\}$ NMR $\left(150.94 \mathrm{MHz}, 300 \mathrm{~K}\right.$, chloroform- $\left.\mathrm{d}_{1}\right): \delta^{13} \mathrm{C}: 131.5(o-\mathrm{Ph}), 130.5(\mathrm{~m}-$ $\mathrm{Ph}), 129.7(p-\mathrm{Ph}), 128.2(i-\mathrm{Ph}), 125.9$ (C5 of $\left.C p^{\prime}\right), 124.8$ (C2 of $\left.C p^{\prime}\right), 122.0$ (i-Cp'), $121.3(\mathrm{Cp}), 117.0$ (C4 of $\left.\mathrm{Cp}^{\prime}\right), 116.4$ (C3 of $\left.\mathrm{Cp}^{\prime}\right), 60.0\left(\mathrm{NCH}_{2} \mathrm{Ph}\right)$, $55.4\left(\mathrm{NCH}_{2} \mathrm{Cp}\right), 39.2\left(\mathrm{NCH}_{3}\right)$.

Synthesis of 14 (red powder, $1.60 \mathrm{~g}$, yield: $52 \%$ ). Amount of substrates/reactants: $7(3.08 \mathrm{~g}, \quad 0.0093 \mathrm{~mol}, \quad 1.0$ eq., $20 \mathrm{~mL}$ dichloromethane); $20 \mathrm{~mL}$ of a HCl-saturated toluene solution. HMRS (Positive mode ESI, dichloromethane): $\mathrm{m} / \mathrm{z}$ calcd. for $\mathrm{C}_{15} \mathrm{H}_{20} \mathrm{NCl}_{2} \mathrm{Ti}[\mathrm{M}-$ $\mathrm{Cl}+\mathrm{H}]^{+} 332.04492$; found 332.04335 (Rel. ab.: 100\%, -4.0 ppm). Elemental Analysis: \% calcd for $\mathrm{C}_{15} \mathrm{H}_{20} \mathrm{Cl}_{3} \mathrm{NTi}: \mathrm{C}, 48.88 ; \mathrm{H}, 5.44 ; \mathrm{N}, 3.69$; Found: $\mathrm{C}$, 49.14; H, 5.82; N, 3.89. ${ }^{1} \mathrm{H}$ NMR ( $600 \mathrm{MHz}, 300 \mathrm{~K}$, chloroform- $\left.\mathrm{d}_{1}\right): \delta^{1} \mathrm{H}$ : 12.77 (broad, $1 \mathrm{H}, \mathrm{NH}), 6.92\left(\mathrm{~m}, 2 \mathrm{H}, \mathrm{H} 2\right.$ of $\left.\mathrm{Cp}^{\prime}\right), 6.67$ (s, 5H, Cp), $6.56(\mathrm{~m}$, $2 \mathrm{H}, H 3$ of $\left.\mathrm{Cp}^{\prime}\right), 4.27\left(\mathrm{~d},{ }^{3} \mathrm{JHH}_{\mathrm{HH}}=6.0 \mathrm{~Hz}, 2 \mathrm{H}, \mathrm{NCH}_{2} \mathrm{C}_{5} \mathrm{H}_{4}\right), 3.68(\mathrm{~m}, 2 \mathrm{H}$, $\left.\mathrm{NCH}_{2} \mathrm{CH}_{2}\right), 2.89\left(\mathrm{~m}, 2 \mathrm{H}, \mathrm{NCH}_{2} \mathrm{CH}_{2}\right), 2.25\left(\mathrm{~m}, 2 \mathrm{H}, \mathrm{NCH}_{2} \mathrm{CH}_{2}\right), 2.10(\mathrm{~m}, 2 \mathrm{H}$, $\left.\mathrm{NCH}_{2} \mathrm{CH}_{2}\right) .{ }^{13} \mathrm{C}\left\{{ }^{1} \mathrm{H}\right\} \mathrm{NMR}\left(150.94 \mathrm{MHz}, 300 \mathrm{~K}\right.$, chloroform-d $\left.\mathrm{d}_{1}\right): \delta^{13} \mathrm{C}: 125.0$ (C2 of $\left.\left.\mathrm{Cp}^{\prime}\right), 123.1 \mathrm{i}-\mathrm{Cp}{ }^{\prime}\right), 121.1(\mathrm{Cp}), 116.2$ ( $\mathrm{C3}$ of $\left.\mathrm{Cp}^{\prime}\right), 54.3\left(\mathrm{NCH}_{2} \mathrm{C}_{5} \mathrm{H}_{4}\right)$, $53.8\left(\mathrm{NCH}_{2} \mathrm{CH}_{2}\right), 23.5\left(\mathrm{NCH}_{2} \mathrm{CH}_{2}\right)$.

Synthesis of 15 (red powder, $0.490 \mathrm{~g}$, yield: $66 \%$ ). Amount of substrates/reactants: 8 ( $0.725 \mathrm{~g}, 0.0018 \mathrm{~mol}, 1$ eq., $5 \mathrm{~mL}$ toluene); $5 \mathrm{~mL}$ of a $\mathrm{HCl}$-saturated toluene solution. HMRS (Positive mode ESI, dichloromethane-methanol): $\mathrm{m} / \mathrm{z}$ calcd. for $\mathrm{C}_{19} \mathrm{H}_{21} \mathrm{NClTi} \quad[\mathrm{M}-\mathrm{Cl}]^{+}$ 362.09189; found 362.09282 (Rel. ab.: $85 \%, 3.3$ ppm). Elemental Analysis: \% calcd for $\mathrm{C}_{25} \mathrm{H}_{26} \mathrm{Cl}_{3} \mathrm{NTi}$ : C, $51.22 ; \mathrm{H}, 6.57 ; \mathrm{N}, 3.51$; Found: $\mathrm{C}$, $50.95 ; \mathrm{H}, 7.64 ; \mathrm{N}, 3.52 .{ }^{1} \mathrm{H}$ NMR $\left(600.23 \mathrm{MHz}, 300 \mathrm{~K}\right.$, chloroform- $\left.\mathrm{d}_{1}\right): \delta^{1} \mathrm{H}$ : 11.62 (broad, $1 \mathrm{H}, \mathrm{NH}), 7.00(\mathrm{~m}, 2 \mathrm{H}, \mathrm{H} 2$ of $\mathrm{Cp}$ ), $6.68(\mathrm{~s}, 5 \mathrm{H}, \mathrm{Cp}), 6.57(\mathrm{~m}$, $2 \mathrm{H}, \mathrm{H} 3$ of $\mathrm{Cp}^{\prime}$ ), $4.35\left(\mathrm{~d},{ }^{3} \mathrm{JNH}_{\mathrm{HN}}=5.2 \mathrm{~Hz}, 2 \mathrm{H}, \mathrm{NCH}_{2} \mathrm{C}_{5} \mathrm{H}_{4}\right), 3.71$ (dsept, ${ }^{3} \mathrm{JHH}_{\mathrm{HH}}$ $\left.=6.7 \mathrm{~Hz},{ }^{3} \mathrm{JHNH}=3.4 \mathrm{~Hz}, 2 \mathrm{H}, \mathrm{NCH}\right), 1.56\left(\mathrm{~d},{ }^{3} \mathrm{JHH}_{\mathrm{HH}}=6.7 \mathrm{~Hz}, 6 \mathrm{H}, \mathrm{NCHCH}_{3}\right)$, $1.51\left(\mathrm{~d},{ }^{3} \mathrm{HHH}_{\mathrm{HH}}=6.7 \mathrm{~Hz}, 6 \mathrm{H}, \mathrm{NCHCH} \mathrm{H}_{3}\right) .{ }^{13} \mathrm{C}\left\{{ }^{3} \mathrm{H}\right\} \mathrm{NMR}(150.94 \mathrm{MHz}, 300 \mathrm{~K}$, chloroform- $d_{1}$ ): $\delta^{13} C_{1}: 127.0$ (C2 of $\left.C p^{\prime}\right), 122.8$ (i-Cp'), $120.9(\mathrm{Cp}), 115.0$ (C3 of $\left.\mathrm{Cp}^{\prime}\right), 55.2(\mathrm{NCH}), 46.6\left(\mathrm{NCH}_{2} \mathrm{C}_{5} \mathrm{H}_{4}\right), 19.3\left(\mathrm{NCHCH}_{3}\right), 18.1$ $\left(\mathrm{NCHCH}_{3}\right)$.

Synthesis of 16 (red powder, $0.100 \mathrm{~g}$, yield: $60 \%$ ). Amount of substrates/reactants: 10 (0.150 g, $0.0005 \mathrm{~mol}, 1.0$ eq., $5 \mathrm{~mL}$ toluene); 5 $\mathrm{mL}$ of a HCl-saturated toluene solution. HMRS (Positive mode ESI, dichloromethane-methanol): $\mathrm{m} / \mathrm{z}$ calcd. for $\mathrm{C}_{25} \mathrm{H}_{26} \mathrm{NCl}_{2} \mathrm{Ti} \quad[\mathrm{M}-\mathrm{Cl}]^{+}$ 
458.09196; found 458.09056 (Rel, ab. 15\%,-2.3 ppm). Elemental Analysis: \% calcd for $\mathrm{C}_{25} \mathrm{H}_{26} \mathrm{Cl}_{3} \mathrm{NTi}: \mathrm{C}, 60.70 ; \mathrm{H}, 5.30 ; \mathrm{N}, 2.83$; Found: $\mathrm{C}$, 60.54; H, 5.13; N, 2.92. ${ }^{1} \mathrm{H}$ NMR $\left(600.23 \mathrm{MHz}, 300 \mathrm{~K}\right.$, chloroform-d $\left.\mathrm{d}_{1}\right): \delta^{1} \mathrm{H}$ : 12.90 (broad, $1 \mathrm{H}, \mathrm{NH}), 7.61(\mathrm{~m}, 4 \mathrm{H}, o-\mathrm{Ph}), 7.45(\mathrm{~m}, 6 \mathrm{H}, m-\mathrm{Ph}$ and $p-\mathrm{Ph})$, 6.96 ( $\mathrm{m}, 2 \mathrm{H}, \mathrm{H} 2$ of $\left.\mathrm{Cp}^{\prime}\right), 6.61$ (s, 5H, Cp), 6.47 (m, 2H, H3 of Cp'), 4.25 (dd, $\left.{ }^{2} \mathrm{JHH}_{\mathrm{HH}}=13.3 \mathrm{~Hz},{ }^{3} \mathrm{JHNH}=4.5 \mathrm{~Hz}, 2 \mathrm{H}, \mathrm{NCH}_{2} \mathrm{Ph}\right), 4.16\left(\mathrm{~d},{ }^{3} \mathrm{JHNH}_{\mathrm{HN}}=4.2 \mathrm{~Hz}, 2 \mathrm{H}\right.$, $\left.\mathrm{NCH}_{2} \mathrm{C}_{5} \mathrm{H}_{4}\right), 4.15\left(\mathrm{dd},{ }^{2} \mathrm{HHH}=13.3 \mathrm{~Hz},{ }^{3} \mathrm{HNH}_{\mathrm{HN}}=4.5 \mathrm{~Hz}, 2 \mathrm{H}, \mathrm{NCH}_{2} \mathrm{Ph}\right) .{ }^{13} \mathrm{C}\left\{{ }^{1} \mathrm{H}\right\}$ NMR $\left(150.94 \mathrm{MHz}, 300 \mathrm{~K}\right.$, chloroform-d $\left.\mathrm{d}_{1}\right): \delta^{13} \mathrm{C}$ : $131.7(o-\mathrm{Ph}), 130.4(p-$ $\mathrm{Ph}$ ), $129.7(m-\mathrm{Ph}), 128.4(i-\mathrm{Ph}), 124.9$ (C2 of $\left.\mathrm{Cp}^{\prime}\right), 122.5$ (i-Cp'), $121.2(\mathrm{Cp})$ 117.3 (C3 of $\left.\mathrm{Cp}^{\prime}\right), 57.5\left(\mathrm{NCH}_{2} \mathrm{Ph}\right), 52.5\left(\mathrm{NCH}_{2} \mathrm{C}_{5} \mathrm{H}_{4}\right)$.

Synthesis of 17 (red powder, $1.86 \mathrm{~g}$, yield: $73 \%$ ). Amount of substrates/reactants: 11 (2.55 g, $0.006 \mathrm{~mol}, 1.0$ eq., $5 \mathrm{~mL}$ toluene); $5 \mathrm{~mL}$ of a HCl-saturated toluene solution. HMRS (Positive mode ESI, dichloromethane): $\mathrm{m} / \mathrm{z}$ calcd. for $\mathrm{C}_{20} \mathrm{H}_{30} \mathrm{NCl}_{2} \mathrm{Ti}[\mathrm{M}+\mathrm{H}]^{+} 402.12322$; found 402.12149 (Rel. ab.: 85\%, -3.6 ppm). Elemental Analysis: \% calcd for $\mathrm{C}_{20} \mathrm{H}_{30} \mathrm{Cl}_{3} \mathrm{NTi}$ : C, 54.76; H, 6.89; N, 3.19; Found: C, 54.57; H, 6.60; N, 2.87. ${ }^{1} \mathrm{H}$ NMR $\left(600.23 \mathrm{MHz}, 300 \mathrm{~K}\right.$, chloroform-d 1 ): $\delta^{1} \mathrm{H}: 10.77$ (broad, $\left.1 \mathrm{H}, \mathrm{NH}\right)$, $6.75\left(\mathrm{~m}, 2 \mathrm{H}, \mathrm{H2}\right.$ of $\mathrm{Cp}$ ) $, 6.65(\mathrm{~s}, 5 \mathrm{H}, \mathrm{Cp}), 6.63\left(\mathrm{~m}, 2 \mathrm{H}, \mathrm{H} 3\right.$ of $\left.\mathrm{Cp}^{\prime}\right), 4.58(\mathrm{~d}$, $\left.{ }^{3} \mathrm{~J}_{\mathrm{HH}}=3.5,2 \mathrm{H}, \mathrm{NCH}_{2} \mathrm{C}_{5} \mathrm{H}_{4}\right), 2.77\left(\mathrm{td}^{2} \mathrm{JHH}_{\mathrm{HH}}{ }^{3} \mathrm{JHH}_{\mathrm{HH}}=13.7 \mathrm{~Hz},{ }^{3} \mathrm{JHH}=3.8 \mathrm{~Hz}\right.$, $\left.2 \mathrm{H}, \mathrm{NC}\left(\mathrm{CH}_{3}\right)_{2} \mathrm{CH}_{2}\right), 1.79\left(\mathrm{~s}, 6 \mathrm{H}, \mathrm{NC}\left(\mathrm{CH}_{3}\right)_{2}\right), 1.78$ (1 overlapping $\mathrm{m}, 1 \mathrm{H}$, $\left.\mathrm{NC}\left(\mathrm{CH}_{3}\right)_{2} \mathrm{CH}_{2} \mathrm{CH}_{2}\right), 1.73\left(\mathrm{~m}, 1 \mathrm{H}, \mathrm{NC}\left(\mathrm{CH}_{3}\right)_{2} \mathrm{CH}_{2} \mathrm{CH}_{2}\right), 1.56$ (dt, ${ }^{2} \mathrm{JHH}=13.7$ $\left.\mathrm{Hz},{ }^{3} \mathrm{JHH}_{\mathrm{HH}}=3.0 \mathrm{~Hz}, 2 \mathrm{H}, \mathrm{NC}\left(\mathrm{CH}_{3}\right)_{2} \mathrm{CH}_{2}\right), 1.46\left(\mathrm{~s}, 6 \mathrm{H}, \mathrm{NC}\left(\mathrm{CH}_{3}\right)_{2}\right) .{ }^{13} \mathrm{C}\left\{{ }^{1} \mathrm{H}\right\}$ $\operatorname{NMR}\left(150.94 \mathrm{MHz}, 300 \mathrm{~K}\right.$, chloroform-d $\left.\mathrm{d}_{1}\right): \delta^{13} \mathrm{C}: 129.9$ (C2 of $\left.\mathrm{Cp}^{\prime}\right), 122.9$ (i- $\mathrm{Cp}$ '), $120.6(\mathrm{Cp}), 112.6$ (C3 of $\left.\mathrm{Cp}{ }^{\prime}\right), 66.9\left(\mathrm{NC}\left(\mathrm{CH}_{3}\right)_{2}\right), 46.1\left(\mathrm{NCH}_{2} \mathrm{C}_{5} \mathrm{H}_{4}\right)$, $36.8 \quad\left(\mathrm{NC}\left(\mathrm{CH}_{3}\right)_{2} \mathrm{CH}_{2}\right), \quad 30.2 \quad\left(\mathrm{NC}\left(\mathrm{CH}_{3}\right)_{2}\right), \quad 22.1 \quad\left(\mathrm{NC}\left(\mathrm{CH}_{3}\right)_{2}\right), \quad 16.2$ $\left(\mathrm{NC}\left(\mathrm{CH}_{3}\right)_{2} \mathrm{CH}_{2} \mathrm{CH}_{2}\right)$.

Synthesis of $18 . \mathrm{TiCl}_{4}(\mathrm{THF})_{2}(0.268 \mathrm{~g}, 0.001 \mathrm{~mol}, 1$ eq. $)$ dissolved in $5 \mathrm{~mL}$ of $\mathrm{E}_{2} \mathrm{O}$ was added dropwise at $0^{\circ} \mathrm{C}$ by cannulation on $4(0.500 \mathrm{~g}, 0.002$ $\mathrm{mol}, 2.0$ eq.) dissolved in $10 \mathrm{~mL}$ of $\mathrm{Et}_{2} \mathrm{O}$ The resulting solution was left to warm up to room temperature and then stirred $30 \mathrm{~min}$. The crude $\mathrm{red} / \mathrm{brown}$ solution was filtered through diatomaceous earth which was then washed $2 \times 5 \mathrm{~mL}$ of $\mathrm{Et}_{2} \mathrm{O}$ and residual starting material. The brown solution was then evaporated to yield a dark brown oil. The compound was purified by crystallization thanks to a biphasic (Dichloromethane: Pentane $1: 3)$ in the Glove box. After removing the mother liquor, red crystals were obtained after washing with pentane and drying $(0.080 \mathrm{~g}$, yield $=15 \%)$. ${ }^{[30]}$ HMRS (Positive mode ESI, dichloromethane): $\mathrm{m} / \mathrm{z}$ calcd. for $\mathrm{C}_{40} \mathrm{H}_{41} \mathrm{~N}_{2} \mathrm{Cl}_{2} \mathrm{Ti}$ $[\mathrm{M}+\mathrm{H}]^{+}$667.21258; found 667.21217 (Rel. ab.: 35\%, 0.137 ppm), $\mathrm{C}_{40} \mathrm{H}_{40} \mathrm{~N}_{2} \mathrm{ClTi}[\mathrm{M}-\mathrm{Cl}]^{+} 631.23586$; found 631.23645 (Rel. ab.: $5 \%, 1.7 \mathrm{ppm}$ ). ${ }^{1} \mathrm{H}$ NMR $\left(600.23 \mathrm{MHz}, 300 \mathrm{~K}\right.$, dichloromethane- $\left.\mathrm{d}_{2}\right): \delta^{1} \mathrm{H}: 7.36(\mathrm{~m}, 8 \mathrm{H}, \mathrm{o}$ $\mathrm{Ph}$ ), 7.32 (m, 8H, $m-\mathrm{Ph}), 7.24$ (m, 4H, p-Ph), 6.35 (m, 2H, H2 of Cp'), 6.25 (m, $2 \mathrm{H}, \mathrm{H} 3$ of $\mathrm{Cp}^{\prime}$ ), 3.53 (broad, 8H, NCH $\mathrm{N}_{2} \mathrm{Ph}$ ), 3.52 (broad, $4 \mathrm{H}, \mathrm{NCH}_{2} \mathrm{C}_{5} \mathrm{H}_{4}$ ). ${ }^{13} \mathrm{C}\left\{{ }^{1} \mathrm{H}\right\}$ NMR $(150.94 \mathrm{MHz}, 300 \mathrm{~K}$, dichloromethane-d 2$): \delta^{13} \mathrm{C}: 139.9(i-\mathrm{Ph})$, 132.2 (i-Cp'), 129.4 (o-Ph), 128.8 ( $m-\mathrm{Ph}), 127.6$ (p-Ph), 124.5 (C2 of Cp'), 117.1 (C3 of $\left.\mathrm{Cp}^{\prime}\right), 58.7\left(\mathrm{NCH}_{2} \mathrm{Ph}\right), 53.6\left(\mathrm{NCH}_{2} \mathrm{C}_{5} \mathrm{H}_{4}\right)$.

Synthesis of 19. A solution of 4 (1.20 g, $0.004 \mathrm{~mol}, 2.1$ eq.) in $15 \mathrm{~mL}$ of THF was added to a freshly prepared solution of $\mathrm{ZrCl}_{4}(\mathrm{THF})_{2}(0.425 \mathrm{mg}$ of $\mathrm{ZrCl}_{4}$ in $7 \mathrm{~mL}$ of THF, $0.002 \mathrm{~mol}, 1.0$ eq.), by cannulation at $-10^{\circ} \mathrm{C}$. The resulting solution was left to warm up to room temperature and then stirred overnight. The crude brown solution was first evaporated. The brown oil obtained was dissolved in $25 \mathrm{~mL}$ of toluene, filtered through diatomaceous earth which was then washed by $4 \times 10 \mathrm{~mL}$ of toluene and residual starting material. The yellow solution was then evaporated to form a brown sticky oil which was stirred overnight in a mixture of Dichloromethane: pentane (1:3) to yield a white precipitate. The precipitate was filtered off, washed with pentane $(2 \times 10 \mathrm{~mL})$ and dried to yield the desired compound. $(0.400$ $\mathrm{g}$, yield $=31 \%$ ). ${ }^{[29]}$ HMRS (Positive mode ESI, dichloromethane): $\mathrm{m} / \mathrm{z}$ calcd. for $\mathrm{C}_{40} \mathrm{H}_{41} \mathrm{~N}_{2} \mathrm{Cl}_{2} \mathrm{Zr}[\mathrm{M}+\mathrm{H}]^{+} 709.16884$; found 709.16653 (Rel. ab.: $15 \%,-3.3 \mathrm{ppm}) .{ }^{1} \mathrm{H}$ NMR $\left(600.23 \mathrm{MHz}, 300 \mathrm{~K}\right.$, benzene- $\left.\mathrm{d}_{6}\right): \delta^{1} \mathrm{H}: 7.32(\mathrm{~m}$, $8 \mathrm{H}, o-\mathrm{Ph}), 7.20(\mathrm{~m}, 8 \mathrm{H}, m-\mathrm{Ph}), 7.10(\mathrm{~m}, 4 \mathrm{H}, p-\mathrm{Ph}), 6.06\left(\mathrm{~m}, 4 \mathrm{H}, \mathrm{H} 2\right.$ of $\left.\mathrm{Cp}^{\prime}\right)$, $5.72\left(\mathrm{~m}, 4 \mathrm{H}, \mathrm{H} 3\right.$ of $\left.\mathrm{Cp}^{\prime}\right), 3.62\left(\mathrm{~s}, 4 \mathrm{H}, \mathrm{NCH}_{2} \mathrm{C}_{5} \mathrm{H}_{4}\right), 3.38\left(\mathrm{~s}, 8 \mathrm{H}, \mathrm{NCH}_{2} \mathrm{Ph}\right)$.
${ }^{13} \mathrm{C}\left\{{ }^{1} \mathrm{H}\right\}$ NMR (150.94 MHz, $300 \mathrm{~K}$, benzene- $\left.\mathrm{d}_{6}\right): \delta^{13} \mathrm{C}: 139.6(i-\mathrm{Ph}), 129.2$ (o-Ph), 128.7 (i-Cp'), $128.6(m-\mathrm{Ph}), 127.4(p-\mathrm{Ph}), 118.4$ (C2 of $\left.C p^{\prime}\right), 113.2$ (C3 of $\left.\mathrm{Cp}^{\prime}\right), 58.1\left(\mathrm{NCH}_{2} \mathrm{Ph}\right), 52.7\left(\mathrm{NCH}_{2} \mathrm{C}_{5} \mathrm{H}_{4}\right)$.

Synthesis of 20. A solution of $3(3.0 \mathrm{~g}, 0.014 \mathrm{~mol}, 2.0 \mathrm{eq}$.) in $70 \mathrm{~mL}$ of THF was added to a freshly prepared solution of $\mathrm{ZrCl}_{4}(\mathrm{THF})_{2}(1.77 \mathrm{~g}$ of $\mathrm{ZrCl}_{4}$ in $30 \mathrm{~mL}$ of THF, $0.008 \mathrm{~mol}, 1.1 \mathrm{eq}$.), by cannulation at $-10^{\circ} \mathrm{C}$. The resulting solution was left to warm up to room temperature and then stirred overnight. The crude brown solution was filtered through diatomaceous earth to remove $\mathrm{KCl}$ salts. Solvent was removed by vacuum pumping and the white precipitate obtained was wash with pentane $(2 \times 20 \mathrm{~mL})$ to afford the desired compound in good yield $\left(2.75 \mathrm{~g}\right.$, yield $=76 \%$ ). ${ }^{[29]} \mathrm{HMRS}$ (Positive mode ESI, dichloromethane): not detected. ${ }^{1} \mathrm{H} \mathrm{NMR}(600.23 \mathrm{MHz}$, $300 \mathrm{~K}$, dichloromethane- $\left.\mathrm{d}_{2}\right): \delta^{1} \mathrm{H}: 6.35\left(\mathrm{~m}, 4 \mathrm{H}, \mathrm{H2}\right.$ of $\left.\mathrm{Cp}^{\prime}\right), 6.33(\mathrm{~m}, 4 \mathrm{H}, H 3$ of $\mathrm{Cp}^{\prime}$ ), 3.66 (s, $\left.4 \mathrm{H}, \mathrm{NCH}_{2} \mathrm{C}_{5} \mathrm{H}_{4}\right), 2.97$ (sept, $\left.{ }^{3} \mathrm{HHH}_{\mathrm{H}}=6.5 \mathrm{~Hz}, 4 \mathrm{H}, \mathrm{NCH}\right), 1.01$ $\left(\mathrm{d},{ }^{3} \mathrm{JHH}=6.5 \mathrm{~Hz}, 24 \mathrm{H}, \mathrm{NCHCH}\right) .{ }^{13} \mathrm{C}\left\{{ }^{1} \mathrm{H}\right\} \operatorname{NMR}(150.94 \mathrm{MHz}, 300 \mathrm{~K}$, dichloromethane- $\mathrm{d}_{2}$ ): $\delta^{13} \mathrm{C}: 136.0$ (i-Cp'), 118.4 (C2 of $\left.\mathrm{Cp}^{\prime}\right), 113.0$ (C3 of $\left.\mathrm{Cp}^{\prime}\right), 48.8(\mathrm{NCH}), 44.8\left(\mathrm{NCH}_{2} \mathrm{C}_{5} \mathrm{H}_{4}\right), 21.2\left(\mathrm{NCHCH}_{3}\right)$.

Synthesis of 22. A solution of $5(1.0 \mathrm{~g}, 0.004 \mathrm{~mol}, 1.0$ eq.) in $30 \mathrm{~mL}$ of THF was cooled down at $-70^{\circ} \mathrm{C}$. Trimethylsilyl chloride $(0.55 \mathrm{~mL}, 4.3 \mathrm{mmol}$, 1.1 eq.) was added dropwise to the solution and the resulting solution was warmed up to room temperature and stirred for $3 \mathrm{~h}$. All volatiles were removed by evaporation to yield a yellow sticky solid. Dissolution of the solid in $30 \mathrm{~mL}$ of pentane and filtration through diatomaceous earth were used to remove $\mathrm{KCl}$ salts. Pentane was evaporated to yield the corresponding silylated amino cyclopentadiene $(0.970 \mathrm{~g}, 0.003 \mathrm{~mol}, 85 \%)$ as a yellow solid. It was dissolved in $40 \mathrm{~mL}$ of toluene, and added at $-30^{\circ} \mathrm{C}$ to a toluenic solution of $\mathrm{TiCl}_{4}(0.36 \mathrm{~mL}, 0.003 \mathrm{~mol}, 1.0$ eq.). The resulting brown solution was left to warm up to room temperature and stirred overnight. A dark brown solution with a black precipitate was obtained. The heterogeneous solution was dried in vacuo. The brownish residue was triturated in pentane $(30 \mathrm{~mL})$ and dried in vacuo. The sticky residue was triturated in cold pentane $(10 \mathrm{~mL})$ and filtered to yield a dark brown precipitate $(1.08 \mathrm{~g}, 87 \%$ step yield, $74 \%$ global yield). HMRS (Positive mode ESI, dichloromethane / MeOH): $\mathrm{m} / \mathrm{z}$ calcd. for $\mathrm{C}_{16} \mathrm{H}_{28} \mathrm{NCl}_{2} \mathrm{TiO}[\mathrm{M}-$ $\mathrm{Cl}+\mathrm{OCH}+\mathrm{H}]^{+}$368.10244; found 368.1074 (Rel. ab.: 100\%, 2.3 ppm). Elemental Analysis: \% calcd for $\mathrm{C}_{15} \mathrm{H}_{24} \mathrm{NCl}_{3} \mathrm{Ti}: \mathrm{C}, 48.35 ; \mathrm{H}, 6.49 ; \mathrm{N}, 3.76$; Found: C, $48.67 ; \mathrm{H}, 6.69 ; \mathrm{N}, 3.63 .{ }^{1} \mathrm{H}$ NMR $(600.23 \mathrm{MHz}, 300 \mathrm{~K}$, benzene$\left.\mathrm{d}_{6}\right): \delta^{1} \mathrm{H}$ : $6.40\left(\mathrm{~m}, 2 \mathrm{H}, \mathrm{H2}\right.$ of $\left.\mathrm{Cp}^{\prime}\right), 6.15\left(\mathrm{~m}, 2 \mathrm{H}, \mathrm{H} 2\right.$ of $\left.\mathrm{Cp}^{\prime}\right), 3.75(\mathrm{~s}, 2 \mathrm{H}$, $\left.\mathrm{NCH}_{2} \mathrm{C}_{5} \mathrm{H}_{4}\right), 1.36\left(\mathrm{~m}, 2 \mathrm{H}, \mathrm{NC}\left(\mathrm{CH}_{3}\right)_{2} \mathrm{CH}_{2} \mathrm{CH}_{2}\right), 1.26\left(\mathrm{~m}, 4 \mathrm{H}, \mathrm{NC}\left(\mathrm{CH}_{3}\right)_{2} \mathrm{CH}_{2}\right)$, $0.82\left(\mathrm{~s}, 12 \mathrm{H}, \mathrm{NC}\left(\mathrm{CH}_{3}\right)_{2}\right) .{ }^{13} \mathrm{C}\left\{{ }^{1} \mathrm{H}\right\} \mathrm{NMR}\left(150.94 \mathrm{MHz}, 300 \mathrm{~K}\right.$, benzene- $\left.\mathrm{d}_{6}\right)$ : $\delta^{13} \mathrm{C}$ : 151.0 (i-Cp'), 123.9 ( $C 2$ of $\left.\mathrm{Cp}^{\prime}\right), 123.5$ ( $C 2$ of $\left.\mathrm{Cp}^{\prime}\right), 55.3\left(\mathrm{NC}\left(\mathrm{CH}_{3}\right)_{2}\right)$, $45.5\left(\mathrm{NCH}_{2} \mathrm{C}_{5} \mathrm{H}_{4}\right), 41.2\left(\mathrm{NC}\left(\mathrm{CH}_{3}\right)_{2} \mathrm{CH}_{2}\right), 27.9$ (broad, $\left.\mathrm{NC}\left(\mathrm{CH}_{3}\right)_{2}\right), 17.8$ $\left(\mathrm{NC}\left(\mathrm{CH}_{3}\right)_{2} \mathrm{CH}_{2} \mathrm{CH}_{2}\right)$.

\section{Acknowledgements}

This work is supported by the CNRS, Universite de Bourgogne, Conseil Régional de Bourgogne through the plan d'actions régional pour l'innovation (PARI), the fonds européen de développement regional (FEDER) programs, the Agence Nationale de la Recherche and Deutsche Forschungsgemeinschaft (MENOLEP project).

Keywords: titanium • zirconium • cyclopentadienyl ligands • amines

[1] a) J. C. Flores, J. C. W. Chien, M. D. Rausch, Organometallics 1994, 13 4140-4142; b) M. S. Blais, J. C. W. Chien, M. D. Rausch, Organometallics 1998, 17, 3775-3783; c) C. Müller, D. Lilge, M. O. 
Kristen, P. Jutzi, Angew. Chem. Int. Ed. 2000, 39, 789-792; d) S. Bradley, K. D. Camm, S. J. Furtado, A. L. Gott, P. C. McGowan, T. J. Podesta, M. Thornton-Pett, Organometallics 2002, 21, 3443-3453.

[2] a) P. J. Shapiro, E. Bunel, W. P. Schaefer, J. E. Bercaw, Organometallics 1990, 9, 867-869; b) J. Okuda, Chem. Ber. 1990, 123, 1649-1651; c) J. C. Stevens, F. J. Timmers, D. R. Wilson, G. F. Schmidt, P. N. Nickias, R K. Rosen, G. W. Knight, S. Y. Lai (The Dow Chemical Company), European Patent Application EP416815A2, 1991; d) J. A. M. Canich (Exxon Chemical Co.) European Patent Application EP420436A1, 1991; (e) A. Bertuleit, M. Könemann, L. Duda, G. Erker, R. Fröhlich, Top. Catal. 1999, 7, 37-44; f) K. Kunz, G. Erker, S. Döring, R. Fröhlich, G. Kehr, J. Am. Chem. Soc. 2001, 123, 6181-6182; g) J. Klosin, W. J. Kruper, P. N. Nickias, G. R. Roof, P. De Waele, K. A. Abboud, Organometallics 2001 20, 2663-2665; h) K. Kunz, G. Erker, S. Döring, S. Bredeau, G. Kehr, R. Fröhlich, Organometallics 2002, 21, 1031-1041; i) J. Klosin, P. P. Fontaine, R. Figueroa, Acc. Chem. Res. 2015, 48, 2004-2016.

[3] a) N. Choi, S.-y. Onozawa, T. Sakakura, M. Tanaka, Organometallics 1997, 16, 2765-2767; b) B. J. Grimmond, J. Y. Corey, Inorg. Chim. Acta 2002, 330, 89-94; c) M. A. Esteruelas, A. M. López, A. C. Mateo, E. Oñate, Organometallics 2005, 24, 5084-5094.

[4] a) P. W. Causey, M. C. Baird, S. P. C. Cole, Organometallics 2004, 23, 4486-4494; b) O. R. Allen, L. Croll, A. L. Gott, R. J. Knox, P. C. McGowan, Organometallics 2004, 23, 288-292; c) G. D. Potter, M. C. Baird, S. P. C. Cole, J. Organomet. Chem. 2007, 692, 3508-3518; d) O. R. Allen, A. L. Gott, J. A. Hartley, J. M. Hartley, R. J. Knox, P. C. McGowan, Dalton Transactions 2007, 5082-5090; e) M. Hogan, J. Claffey, C. Pampillón, R. W. G. Watson, M. Tacke, Organometallics 2007, 26, 2501-2506; f) C Pampillón, J. Claffey, K. Strohfeldt, M. Tacke, Eur. J. Med. Chem. 2008 43, 122-128; g) K. Strohfeldt, M. Tacke, Chem. Soc. Rev. 2008, 37 1174-1187; h) G. D. Potter, M. C. Baird, S. P. C. Cole, Inorg. Chim. Acta 2010, 364, 16-22.

[5] I. R. Butler, Eur. J. Inorg. Chem. 2012, 2012, 4387-4406.

[6] S. K. Mohapatra, S. Büschel, C. Daniliuc, P. G. Jones, M. Tamm, J. Am. Chem. Soc. 2009, 131, 17014-17023.

[7] a) T. Kauffmann, J. Ennen, H. Lhotak, A. Rensing, F. Steinseifer, A. Woltermann, Angew. Chem. Int. Ed. 1980, 19, 328-329; b) T.-F. Wang, T.-Y. Lee, Y.-S. We, L.-K. Liou, J. Organomet. Chem. 1991, 403, 353 358; c) W. Tein-Fu, L. Tsung-Yi, C. Jim-Wen, O. Chi-Wi, J. Organomet. Chem. 1992, 423, 31-38; d) A. K. Hughes, A. Meetsma, J. H. Teuben, Organometallics 1993, 12, 1936-1945; e) C. Qian, J. Guo, C. Ye, J. Sun, P. Zheng, J. Chem. Soc., Dalton Trans. 1993, 3441-3445; f) P. Jutzi, J. Dahlhaus, Coord. Chem. Rev. 1994, 137, 179-199; g) W. A. Herrmann, M. J. A. Morawietz, T. Priermeier, K. Mashima, J. Organomet. Chem. 1995, 486, 291-295; h) P. Jutzi, U. Siemeling, J. Organomet. Chem. 1995 500, 175-185; i) A. A. H. van der Zeijden, Tetrahedron: Asymmetry 1995 6, 913-918; j) P. Jutzi, T. Redeker, B. Neumann, H.-G. Stammler, Organometallics 1996, 15, 4153-4161; k) P. C. McGowan, C. E. Hart, B. Donnadieu, R. Poilblanc, J. Organomet. Chem. 1997, 528, 191-194; I) Q. Yanlong, G. Rongwei, H. Jiling, Y. Qingchun, Polyhedron 1997, 16, 195 198; m) M. A. D. McGowan, P. C. McGowan, Inorg. Chem. Commun. 2000, 3, 337-340; n) C. Müller, D. Vos, P. Jutzi, J. Organomet. Chem. 2000, 600, 127-143; o) D. Kunz, R. Fröhlich, G. Erker, Organometallics 2001, 20, 572-574; p) S. Bradley, M. M. Corradi, K. D. Camm, S. J. Furtado, P. C. McGowan, R. Mumtaz, M. Thornton-Pett, J. Organomet Chem. 2002, 656, 49-56; q) M. Tacke, L. T. Allen, L. Cuffe, W. M. Gallagher, Y. Lou, O. Mendoza, H. Müller-Bunz, F.-J. K. Rehmann, N. Sweeney, J. Organomet. Chem. 2004, 689, 2242-2249.
[8] G. Erker, Coord. Chem. Rev. 2006, 250, 1056-1070.

[9] a) K. Hafner, K. H. Vöpel, G. Ploss, C. König, Justus Liebigs Annalen der Chemie 1963, 661, 52-75; b) A. Bertuleit, C. Fritze, G. Erker, R. Fröhlich, Organometallics 1997, 16, 2891-2899.

[10] a) A. Kreutzberger, K. Kolter, Liebigs Ann. Chem. 1986, 1986, 374-379; b) G. E. Herberich, U. Englert, T. Wirth, Eur. J. Inorg. Chem. 2005, 2005, 4924-4935.

[11] a) P. Jutzi, T. Heidemann, B. Neumann, H. G. Stammler, Synthesis 1992 1992, 1096-1098; b) C. Wang, G. Erker, G. Kehr, K. Wedeking, R Fröhlich, Organometallics 2005, 24, 4760-4773.

[12] A. R. Katritzky, X. Lan, J. Z. Yang, O. V. Denisko, Chem. Rev. 1998, 98, 409-548.

[13] a) A. R. Katritzky, S. Rachwal, B. Rachwal, J. Chem. Soc., Perkin Trans. 11987, 799-804; b) A. R. Katritzky, K. Yannakopoulou, P. Lue, D. Rasala, L. Urogdi, J. Chem. Soc., Perkin Trans. 11989, 225-233.

[14] ${ }^{15} \mathrm{~N}$ NMR chemical shifts of $\delta \sim-338 \mathrm{ppm}$ for zirconocene complexes with a pendant amine function have been observed. This signal goes to higher field $(\Delta \delta \sim-20 \mathrm{ppm})$ if nitrogen to zirconium interaction is present, see for example: J. Pflug, A. Bertuleit, G. Kehr, R. Fröhlich, G. Erker, Organometallics 1999, 18, 3818-3826.

[15] B. Cordero, V. Gomez, A. E. Platero-Prats, M. Reves, J. Echeverria, E. Cremades, F. Barragan, S. Alvarez, Dalton Transactions 2008, 28322838.

[16] a) A. A. H. van der Zeijden, J. Organomet. Chem. 1996, 518, 147-153; b) P. Jutzi, T. Redeker, B. Neumann, H.-G. Stammler, J. Organomet. Chem. 1997, 533, 237-245.

[17] a) D. F. Wass, A. M. Chapman, in Transition Metal-Containing Systems, Springer Verlag, Berlin-Heidelberg, 2013, pp. 261-280; b) S. R. Flynn, D. F. Wass, ACS Catalysis 2013, 3, 2574-2581.

[18] T. K. Panda, M. T. Gamer, P. W. Roesky, Organometallics 2003, 22, 877878.

[19] L. E. Manxzer, J. Deaton, P. Sharp, R. R. Schrock, in Inorg. Synth., John Wiley \& Sons, Inc., 2007, pp. 135-140.

[20] A. F. Reid, P. C. Wailes, J. Organomet. Chem. 1964, 2, 329-335.

[21] G. H. Llinás, M. Mena, F. Palacios, P. Royo, R. Serrano, J. Organomet. Chem. 1988, 340, 37-40.

[22] Armarego, W. L. F.; Chai, C. L. L. Purification of laboratory chemicals 6 th ed. Elsevier/Butterworth-Heinemann: Amsterdam ; Boston 2009.

[23] M. C. Burla, R. Caliandro, B. Carrozzini, G. L. Cascarano, C. Cuocci, C. Giacovazzo, M. Mallamo, A. Mazzone, G. Polidori, J. Appl. Crystallogr. 2015, 48, 306-309.

[24] G. Sheldrick, Acta Crystallographica Section A 2008, 64, 112-122.

[25] G.Sheldrick, Acta Crystallographica Section A 2015, 71, 3-8.

[26] G. Sheldrick, Acta Crystallographica Section C 2015, 71, 3-8.

[27] O. V. Dolomanov, L. J. Bourhis, R. J. Gildea, J. A. K. Howard, H. Puschmann, J. Appl. Crystallogr. 2009, 42, 339-341.

[28] Satisfactory elemental analyses were not obtained due to the high airsensitivity of the compounds and / or the presence of residual byproducts.

[29] Satisfactory elemental analyses were not obtained due to the presence of residual $\mathrm{LiCl}$.

[30] Elemental analysis was not performed on this compound due to a lack of product. 